\title{
Contributions of Various Noncovalent Bonds to the Interaction between an Amide and S-Containing Molecules
}

\author{
Upendra Adhikari and Prof. Steve Scheiner* \\ Department of Chemistry and Biochemistry \\ Utah State University \\ Logan, UT 84322-0300
}

\begin{abstract}
$\mathrm{N}$-methylacetamide, a model of the peptide unit in proteins, is allowed to interact with $\mathrm{CH}_{3} \mathrm{SH}$, $\mathrm{CH}_{3} \mathrm{SCH}_{3}$, and $\mathrm{CH}_{3} \mathrm{SSCH}_{3}$ as models of S-containing amino acid residues. All of the minima are located on the ab initio potential energy surface of each heterodimer. Analysis of the forces holding each complex together identifies a variety of different attractive forces, including $\mathrm{SH} \cdots \mathrm{O}, \mathrm{NH} \cdots \mathrm{S}$, $\mathrm{CH} \cdots \mathrm{O}, \mathrm{CH} \cdots \mathrm{S}, \mathrm{SH} \cdots \pi$, and $\mathrm{CH} \cdots \pi \mathrm{H}$-bonds. Other contributing noncovalent bonds involve charge transfer into $\sigma^{*}$ and $\pi^{*}$ antibonds. Whereas some of the H-bonds are strong enough that they represent the sole attractive force in several dimers, albeit not usually in the global minimum, charge-transfer type noncovalent bonds play only a supporting role. The majority of dimers are bound by a collection of several of these attractive interactions. The $\mathrm{SH} \cdots \mathrm{O}$ and $\mathrm{NH} \cdots \mathrm{S}$ H-bonds are of comparable strength, followed by $\mathrm{CH} \cdots \mathrm{O}$ and $\mathrm{CH} \cdots \mathrm{S}$.
\end{abstract}

*email: steve.scheiner@usu.edu

fax 435-797-3390

keywords: weak H-bonds; charge-transfer; noncovalent bonds; NBO; ab initio calculation 


\section{INTRODUCTION}

Because of its prevalence in proteins, the peptide linkage has been studied extensively, and there is a great deal of information available about its proclivity toward planarity, its flexibility, and its electronic structure. The peptide group involves itself in a multitude of H-bonds within proteins, which are largely responsible for a great deal of secondary structure, as in $\alpha$-helices and $\beta$-sheets. For this reason, a large amount of effort has been expended in elucidating details about the ability of both the $\mathrm{NH}$ and $\mathrm{C}=\mathrm{O}$ groups of the peptide to engage in H-bonds, not only with other peptide groups, but also with some of the more widely occurring amino acid side chains.

Whereas many of the polar side chains, e.g. Ser, Lys, His, would of course form H-bonds with the proton-donating and accepting sites of the - $\mathrm{CONH}$ - peptide group, the situation is less clear for those containing S. The SH group of Cys certainly offers the possibility of a SH・•O or SH・•N H-bond, but SH is not known as a strong proton donor ${ }^{[1-3]}$. In the case of Met, with no SH the only H-bonding opportunity would utilize $\mathrm{S}$ as proton-acceptor, in the capacity of which this atom is again not very potent. Another option might utilize a $\mathrm{CH}$ as a proton donor, which previous work has suggested can provide a fairly strong $\mathrm{H}$-bond under certain circumstances ${ }^{[4-12]}$ including protein models ${ }^{[13-15]}$. This $\mathrm{CH}$ might arise from the $\mathrm{C}^{\alpha} \mathrm{H}$ element of the protein skeleton ${ }^{[16-18]}$ or from the alkyl chains which are part of the S-containing residues.

There are options for attractive contacts other than H-bonding. As an example, there have been numerous observations of pairs of carbonyl groups ${ }^{[19]}$ wherein the two groups are oriented either perpendicular or parallel to one another, a pattern that was originally attributed to dipolar interactions ${ }^{[20-}$ ${ }^{22]}$. This idea was further elaborated, invoking the concept of anisotropy of the electrostatic field around the $\mathrm{O}$ atom ${ }^{[23,24]}$. Other work ${ }^{[25-27]}$ suggested that the transfer of charge from an O lone pair to a CO $\pi^{*}$ antibonding orbital was a major contributor as well.

Molecules containing sulfur are also capable of interactions other than H-bonds. Early analyses of crystal structures ${ }^{[28]}$ revealed a tendency of nucleophiles to approach $\mathrm{S}$ along an extension of one of its covalent bonds, a pattern that won some initial support from calculations ${ }^{[29]}$. Subsequent crystal database analyses ${ }^{[30,31]}$ confirmed this geometric preference within the context of both proteins and smaller molecules. Other groups ${ }^{[32-35]}$ attributed the attraction, at least in part, to charge transfer from the nucleophilic atom's lone pair to the antibonding orbital of the C-S bond, although induction and dispersion can be important as well ${ }^{[36]}$. Very recent research in this laboratory ${ }^{[37-41]}$ has amplified and generalized the concept of charge transfer from the lone pair of an atom on one molecule to a $\sigma^{*}$ antibonding orbital on its partner, to a range of atoms that include $\mathrm{P}$ and $\mathrm{Cl}$. The $\mathrm{S}$ atom too has been 
shown to be a prime candidate for accepting this charge into a $\mathrm{S}-\mathrm{X}$ antibond to form surprisingly strong noncovalent bonds ${ }^{[42-45]}$. The range of possibilities for interactions with an amide group could thus be expanded to include a noncovalent bond between $\mathrm{S}$ and the $\mathrm{O}$ or $\mathrm{N}$ atoms of the amide.

The principal purpose of the present communication is an exploration of the full variety of different sorts of interactions that may occur between the peptide linkage of a protein and S-containing amino acid residues, and to sort out which noncovalent bonds might predominate. The N-methylacetamide (NMA) molecule in its trans geometry, which brackets an amide by a pair of $\mathrm{C}$ atoms as would occur along the protein backbone, is taken as a model of the peptide unit. $\mathrm{CH}_{3} \mathrm{SH}$ is used to represent the Cys side chain, and $\mathrm{CH}_{3} \mathrm{SCH}_{3}$ is a prototype of Met. The disulfide bond that frequently connects Cys side chains is modeled by $\mathrm{CH}_{3} \mathrm{SSCH}_{3}$. For each pair of molecules, the potential energy surface is thoroughly searched for all minima. Comparisons of the energetics of the various structures provide information about the relative strength of each sort of interaction contained therein. The analysis also brings to light some new noncovalent bonds that have not been previously reported.

\section{COMPUTATIONAL METHODS}

$\mathrm{Ab}$ initio calculations were carried out via the Gaussian 09 package ${ }^{[46]}$. Geometries were optimized at the ab initio MP2/aug-cc-pVDZ level which has been shown to be of high accuracy, especially for weak intermolecular interactions of the type of interest here ${ }^{[35,47-52]}$ where the data are in close accord with $\operatorname{CCSD}(\mathrm{T})$ values with larger basis sets ${ }^{[38,53,54]}$ and in excellent agreement with experimental energetics ${ }^{[55]}$. Binding energies were computed as the difference in energy between the dimer, and the sum of the optimized energies of the isolated monomers, corrected for basis set superposition error by the counterpoise procedure ${ }^{[56]}$. For purposes of identifying all stabilizing interactions within each dimer, and estimating the strength of each, natural bond orbital (NBO) analysis ${ }^{[57,58]}$ was carried out via the procedures contained within Gaussian.

\section{RESULTS}

Each of the three S-containing molecules was paired with NMA, and the potential energy surface was thoroughly searched so as to identify all minima.

\section{$\underline{\mathrm{CH}}_{3} \underline{\mathrm{SH}}$}

Perhaps emblematic of this entire problem, the global minimum of the complex between NMA and $\mathrm{CH}_{3} \mathrm{SH}$ is a product of a number of contributing noncovalent bonds, none of which are dominant by any means. This structure, illustrated in Fig 1a, has a total binding energy of $4.60 \mathrm{kcal} / \mathrm{mol}$. Based upon the

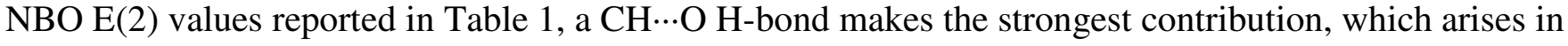
part from an interaction with the $\mathrm{O}$ lone pairs $(\mathrm{CH} \cdots \mathrm{O})$ in Table 1 of $1.53 \mathrm{kcal} / \mathrm{mol}$, combined with 1.11 
$\mathrm{kcal} / \mathrm{mol}$ from electron donation by the $\mathrm{CO} \pi$-bonding orbital. This fairly strong interaction is consistent with the close $\mathrm{R}(\mathrm{H} \cdots \mathrm{O})$ contact of $2.31 \AA$, shorter than a typical CH..O H-bond, particularly one involving a methyl group. Also contributing to the binding energy is a $\mathrm{CH} \cdots \mathrm{S} \mathrm{H}$-bond, with a value of $\mathrm{E}(2)$ of $1.06 \mathrm{kcal} / \mathrm{mol}$, even though the $\mathrm{H}$ and $\mathrm{S}$ atoms are separated by $3.02 \AA$. The last component with an $\mathrm{E}(2)$ above the $0.5 \mathrm{kcal} / \mathrm{mol}$ threshold is one involving electron donation from the $\mathrm{S}$ lone pairs to the $\mathrm{CO} \pi^{*}$ antibonding orbital, with $\mathrm{S}$ separated from the pertinent $\mathrm{O}$ atom by $3.39 \AA$, and an even closer $\mathrm{R}(\mathrm{S} \cdots \mathrm{C})$ contact of $3.30 \AA$. This latter interaction is rather unusual, one that is not commonly observed. Its absence from the literature is understandable as it occurs only in tandem with other, stronger, noncovalent bonds, which would normally mask its presence.

An SH... H H-bond makes an appearance in the second most stable minimum, $\mathbf{1 b}$, which is bound by $4.27 \mathrm{kcal} / \mathrm{mol}$. This H-bond arises from two elements. Electron donation to the $\sigma^{*}(\mathrm{SH})$ orbital from the $\mathrm{O}$ lone pairs amounts to $2.77 \mathrm{kcal} / \mathrm{mol}$, which accounts for the normal $\mathrm{SH} \cdot \mathrm{O} \mathrm{H}$-bond. This $\mathrm{H}$-bond is fairly long, with $\mathrm{R}(\mathrm{H} \cdots \mathrm{O})=2.23 \AA$, and is further weakened by its $39^{\circ}$ deviation from linearity. This attraction is complemented by a value of $\mathrm{E}(2)$ of $1.84 \mathrm{kcal} / \mathrm{mol}$ for the density extracted from the $\mathrm{CO} \pi$ orbital, surprisingly strong for what amounts to a $\mathrm{SH} \cdots \pi \mathrm{H}$-bond. This complex also contains a secondary $\mathrm{CH} \cdots \mathrm{S}$ H-bond, allowing the $\mathrm{S}$ atom to serve as both proton donor and acceptor. A SH $\cdots \mathrm{O} H-$ bond dominates the next minimum on the surface, slightly less stable than its predecessor. In fact, there are no discernible secondary interactions in 1c, and $\mathrm{E}(2)$ for this $\mathrm{H}$-bond is $10.2 \mathrm{kcal} / \mathrm{mol}$, facilitated in part by a very nearly linear $\theta(\mathrm{SH} \cdot \cdot \mathrm{O})$ of $177^{\circ}$. Comparison of $\mathbf{1 b}$ and $\mathbf{1 c}$ indicates that the benefit of forming $\mathrm{CH} \cdots \mathrm{S}$ and $\mathrm{SH} \cdots \pi \mathrm{H}$-bonds, even weak ones, is worth the stretching and bending of the $\mathrm{SH} \cdots \mathrm{O}$ in $\mathbf{1 b}$.

The next minimum on the surface, bound by $4.06 \mathrm{kcal} / \mathrm{mol}$, is reminiscent of the global minimum in terms of its constituent stabilizing forces. It too contains $\mathrm{CH} \cdots \mathrm{O}$ and $\mathrm{CH} \cdots \mathrm{S}$ H-bonds, and a repeat of a charge transfer from the S lone pairs to the $\pi^{*} \mathrm{CO}$ orbital. It also contains a very weak SH$\cdots \pi \mathrm{H}$-bond.

Structure 1e is unique from the others. Bound by $4.03 \mathrm{kcal} / \mathrm{mol}$, its strongest component arises from a $\mathrm{CH} \mathrm{H}$-bond to the amide $\mathrm{O}$ atom, with both the $\mathrm{O}$ lone pairs and the $\mathrm{CO} \pi$ orbital donating charge. But 1e also contains a contribution whereby charge is transferred from the $\mathrm{N}$ lone pair into the $\sigma^{*}$ antibonding orbital of the SH bond. This transfer is facilitated by the overlap of the $\mathrm{N}$ lone pair with the lobe of the $\sigma^{*}$ orbital proximate to the $\mathrm{S}$ atom, not the usual $\mathrm{H}$ as in a $\mathrm{H}$-bond. This overlap is facilitated by the rotation of the $\mathrm{S}-\mathrm{H}$ bond some $168^{\circ}$ away from the $\mathrm{N}$ atom. Nonetheless, the latter HS $\cdots \mathrm{N}$ noncovalent bond contributes only $0.55 \mathrm{kcal} / \mathrm{mol}$, much smaller than the combined $\mathrm{E}(2)$ of 2.82 $\mathrm{kcal} / \mathrm{mol}$ for the $\mathrm{CH} \cdots \mathrm{O} \mathrm{H}-$ bond, so is not dominating by any means. 
There were six other minima identified on the surface of the $\mathrm{NMA} / \mathrm{CH}_{3} \mathrm{SH}$ heterodimer, with binding energies varying from 3.99 down to $3.38 \mathrm{kcal} / \mathrm{mol}$. (These structures are displayed graphically in Fig S1 of the Supplemental Information.) The contributing interactions are largely repeats of those incorporated into the more stable minima, albeit weaker versions. The only new interaction is the $\mathrm{NH} \cdots \mathrm{S}$ H-bond in $\mathbf{1 h}$ which is the only contributor to the dimer in which it occurs. Another weakly bound minimum is of interest as it contains a $\mathrm{CH} \cdots \mathrm{O} \mathrm{H}$-bond as its sole contributor. Comparison of these two complexes with 1c leads to an estimation of the $\mathrm{SH} \cdots \mathrm{O}, \mathrm{NH} \cdots \mathrm{S}$, and $\mathrm{CH} \cdots \mathrm{O} \mathrm{H}$-bond energies of $4.12,3.95$, and $3.52 \mathrm{kcal} / \mathrm{mol}$, respectively.

\section{$\mathrm{CH}_{3} \underline{\mathrm{SCH}}_{3}$}

Replacement of the $\mathrm{H}$ of $\mathrm{CH}_{3} \mathrm{SH}$ by a second methyl group eliminates the possibility of a $\mathrm{SH} \cdot \mathrm{O} \mathrm{H}-$ bond which is probably the strongest single noncovalent bond, present in several of the lower-energy minima of its complex with NMA. As illustrated in Fig 2, the global minimum of the $\mathrm{NMA} / \mathrm{CH}_{3} \mathrm{SCH}_{3}$

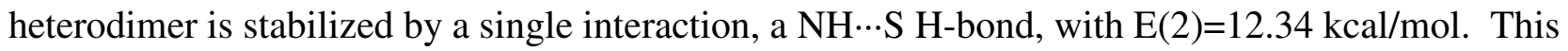
$\mathrm{NH} \cdots \mathrm{S}$ H-bond is stronger than the same interaction in $\mathrm{CH}_{3} \mathrm{SH}, 4.93 \mathrm{vs} 3.95 \mathrm{kcal} / \mathrm{mol}$, and $\mathrm{R}(\mathrm{H} \cdots \mathrm{S})$ equal to $2.455 \AA$ as compared to $2.534 \AA$. This enhanced H-bond is likely due to the effect of the second methyl group bound to $\mathrm{S}$.

Only slightly higher in energy is structure $\mathbf{2 b}$ which contains a number of different interactions, listed in Table 2. One of them involves charge transfer from $\mathrm{S}$ lone pairs to the $\pi^{*} \mathrm{CO}$ antibonding orbital. The $\mathrm{O}$ atom serves as proton acceptor for two methyl $\mathrm{CH}$ groups, both less than $2.5 \AA$ in length. These same H-bonds are both supplemented by charge transfer from the $\mathrm{CO} \pi$ orbital, so can be termed $\mathrm{CH} \cdots \pi$.

A charge transfer from the $\mathrm{N}$ lone pair of NMA to a $\mathrm{SC} \sigma^{*}$ antibonding orbital is observed in the third minimum 2c, higher in energy than $\mathbf{2 a}$ by $0.7 \mathrm{kcal} / \mathrm{mol}$. The $\mathrm{R}(\mathrm{N} \cdots \mathrm{S})$ distance is $3.28 \AA$, and $\theta(\mathrm{CS} \cdot \mathrm{N})$ within $4^{\circ}$ of linearity, both of which assist the formation of this bond. However, a $\mathrm{CH} \cdots \mathrm{O} \mathrm{H}-$ bond may be more important, with an $\mathrm{E}(2)$ of $1.81 \mathrm{kcal} / \mathrm{mol}$, as compared to $0.75 \mathrm{kcal} / \mathrm{mol}$ for the $\mathrm{CS} \cdots \mathrm{N}$ bond. (Structure $\mathbf{2 d}$ is very similar to $\mathbf{2 c}$, so is relegated to the Supplementary Information Fig S2.) A bond of similar CS $\cdots \mathrm{N}$ type is contained within the next minimum $\mathbf{2 e}$ as well. However, its smaller $\mathrm{E}(2)$ of $0.57 \mathrm{kcal} / \mathrm{mol}$ is overshadowed by both $\mathrm{NH} \cdots \mathrm{S}$ and $\mathrm{CH} \cdots \mathrm{S}$ H-bonds. Somewhat higher in energy is configuration $\mathbf{2 f}$ with only one primary source of stability, a $\mathrm{CH} \cdots \mathrm{O}$ H-bond, but a short and strong one, with $\mathrm{R}(\mathrm{H} \cdots \mathrm{O})=2.28 \AA$ and $\mathrm{E}(2)=4.41 \mathrm{kcal} / \mathrm{mol}$. The binding energy of this pure $\mathrm{CH} \cdots \mathrm{O} \mathrm{H}-$ bond of $3.46 \mathrm{kcal} / \mathrm{mol}$ is understandably quite similar to the value of $3.52 \mathrm{kcal} / \mathrm{mol}$ for this same interaction with $\mathrm{CH}_{3} \mathrm{SH}$. 
The next two minima (pictured in Fig. S2) are also stabilized by $\mathrm{CH}$... O H-bonds, followed by a weaker complex, with a stabilization energy of $1.91 \mathrm{kcal} / \mathrm{mol}$, that contains a number of different noncovalent interactions, but $\mathrm{E}(2)$ of all of which are only around $0.52 \mathrm{kcal} / \mathrm{mol}$.

The comparison of the complexes of $\mathrm{NMA}$ with $\mathrm{CH}_{3} \mathrm{SH}$ and $\mathrm{CH}_{3} \mathrm{SCH}_{3}$ indicates that the loss of the possibility of a SH‥O H-bond in the latter case does not necessarily result in a weaker complex. On the contrary, the $\mathrm{NH} \cdots \mathrm{S}$ H-bond that occurs in $\mathbf{2 a}$ makes for a stronger interaction than any involving $\mathrm{CH}_{3} \mathrm{SH}$. The structure which contains a $\mathrm{NH} \cdots \mathrm{S} \mathrm{H}$-bond for $\mathrm{NMA} / \mathrm{CH}_{3} \mathrm{SH}$ is somewhat weaker, and represents only the eighth most stable complex on its potential energy surface. It would appear that the second methyl group makes $\mathrm{S}$ a stronger proton acceptor, such that the $\mathrm{NH} \cdots \mathrm{S} \mathrm{H}$-bond is the predominant factor in the global minimum of $\mathrm{NMA} / \mathrm{CH}_{3} \mathrm{SCH}_{3}$.

\section{$\underline{\mathrm{CH}}_{3} \underline{\mathrm{SSCH}}_{3}$}

Like $\mathrm{CH}_{3} \mathrm{SCH}_{3}, \mathrm{CH}_{3} \mathrm{SSCH}_{3}$ too cannot form a SH$\cdots \mathrm{O}$ H-bond. However, unlike $\mathrm{CH}_{3} \mathrm{SCH}_{3}$, a NH$\cdots \mathrm{S}$ $\mathrm{H}$-bond is not involved in the global minimum of $\mathrm{NMA} / \mathrm{CH}_{3} \mathrm{SSCH}_{3}$. The presence of a second $\mathrm{S}$ atom adjacent to the first weakens $\mathrm{S}$ as proton acceptor, such that a $\mathrm{NH} \cdots \mathrm{S}$ H-bond appears for the first time only in the eighth minimum in its surface. In the only geometry in which $\mathrm{NH} \cdots \mathrm{S}$ acts as the sole binding agent, its $\mathrm{H}$-bond energy is $4.40 \mathrm{kcal} / \mathrm{mol}$, intermediate between the $\mathrm{CH}_{3} \mathrm{SH}$ and $\mathrm{CH}_{3} \mathrm{SCH}_{3}$ cases.

The global minimum in the $\mathrm{CH}_{3} \mathrm{SSCH}_{3} / \mathrm{NMA}$ heterodimer is characterized by the multiple stabilizing interactions indicated in Table 3. As illustrated in Fig 3a, there is a $\mathrm{CH} \cdots \mathrm{O} / \pi \mathrm{H}$-bond, in which electrons are donated not only by the $\mathrm{O}$ lone pairs $(1.22 \mathrm{kcal} / \mathrm{mol})$ but even more so by the $\mathrm{CO} \pi$ bond $(2.75 \mathrm{kcal} / \mathrm{mol})$. A methyl group on the NMA engages in a $\mathrm{CH} \cdot \cdot \mathrm{O} \mathrm{H}$-bond with $\mathrm{S}$, and there is another contribution involving charge transfer from the $\mathrm{S}$ lone pairs to the $\mathrm{CO} \pi^{*}$ antibonding orbital. Altogether, these interactions add up to a total stabilization energy of more than $5 \mathrm{kcal} / \mathrm{mol}$, the largest of any of the complexes considered here. There is another minimum, $\mathbf{3 b}$, almost a mirror image of the first, that contains very similar interactions, and a binding energy only $0.1 \mathrm{kcal} / \mathrm{mol}$ smaller.

The next minimum $3 \mathrm{c}$ also contains $\mathrm{CH} \cdot \mathrm{O}$ and $\mathrm{CH} \cdot \mathrm{S}$ H-bonds, as well as $\pi^{*} \mathrm{CO} \cdot \mathrm{S}$. What is new here, however, are a pair of interactions that involve charge transfer into the SS $\sigma^{*}$ antibonding orbital. Some density is extracted from the $\mathrm{CO} \pi$ bond, but some also from the $\mathrm{CO} \pi^{*}$ antibond. As is true for most NBO virtual orbitals, the $\pi^{*} \mathrm{CO}$ is partially occupied. Nonetheless, its willingness to part with a portion of its small occupation to the benefit of the SS $\sigma^{*}$ orbital is unexpected. Indeed, both the $\pi$ and $\pi^{*}$ orbitals contribute a like amount of $0.79 \mathrm{kcal} / \mathrm{mol}$ to the overall stability of this complex. It is these two charge transfer interactions that compensate for the weaker $\mathrm{CH} \cdot \cdot \mathrm{O}$ and $\mathrm{CH} \cdot \mathrm{S} \mathrm{H}$-bonds, imparting a stabilization energy of $4.90 \mathrm{kcal} / \mathrm{mol}$ to this structure. Indeed, $\mathrm{CH} \cdot \cdot \mathrm{O}$ and $\mathrm{CH} \cdot \mathrm{S} \mathrm{H}$-bonds occur in pretty 
much all of the minima of this pair of molecules, whether charge is extracted from just the proton acceptor lone pairs or from the $\mathrm{CO} \pi$ bond as well.

A NH・S H-bond makes its first appearance in the complex $3 \mathbf{h}$ with a binding energy of 4.48 $\mathrm{kcal} / \mathrm{mol}, 0.6 \mathrm{kcal} / \mathrm{mol}$ less than that of the global minimum. It is supplemented by a $\mathrm{CH} \cdot \cdot \mathrm{S} \mathrm{H}-$ bond in that structure, but is fully responsible for the binding of $4.40 \mathrm{kcal} / \mathrm{mol}$ of the next minimum $3 \mathbf{i}$. The next minimum $3 \mathbf{j}$ repeats some of the prior interactions, including the donation from both the $\pi$ and $\pi^{*} \mathrm{CO}$ orbitals into $\sigma^{*}(\mathrm{SS})$.

A new interaction arises in structure 3l, one in which charge is transferred from the $\mathrm{N}$ lone pair into a $\sigma^{*}(\mathrm{CS})$ antibonding orbital. But despite the $\theta(\mathrm{N} \cdot \mathrm{SC})$ angle of $170^{\circ}, \mathrm{E}(2)$ is only $0.65 \mathrm{kcal} / \mathrm{mol}$ for this bond, far less than the $7.37 \mathrm{kcal} / \mathrm{mol}$ arising from the $\mathrm{NH} \cdots \mathrm{S} \mathrm{H}$-bond. Rather than the CS antibond, the $\mathrm{SS} \sigma^{*}$ orbital is the recipient of charge in the next minimum $\mathbf{3 m}$, this time extracted from both the $\mathrm{N}$ lone pair and the $\mathrm{CO} \pi^{*}$ orbital. $\mathrm{A} \mathrm{N}_{\mathrm{lp}} \rightarrow \sigma^{*}(\mathrm{CS})$ transfer occurs in the next minimum as well, this time

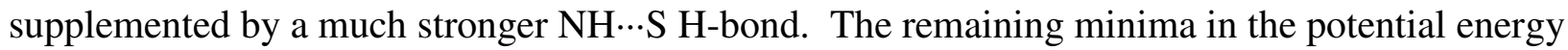
surface of this heterodimer (see Fig S3) all contain some combination of $\mathrm{NH} \cdot \mathrm{S}, \mathrm{CH} \cdot \mathrm{N}, \mathrm{CH} \cdot \mathrm{O}$, and $\mathrm{CH} \cdot$.S H-bonds. The binding energies of these last few minima vary from 4.1 down to $2.1 \mathrm{kcal} / \mathrm{mol}$.

With particular respect to $\mathrm{CH} \cdots \mathrm{O} \mathrm{H}$-bonds, the geometry with this as its sole contributor leads to an estimate of $\mathrm{CH} \cdots \mathrm{O} \mathrm{H}$-bond energy of $3.74 \mathrm{kcal} / \mathrm{mol}$, slightly greater than those for $\mathrm{CH}_{3} \mathrm{SH}$ and $\mathrm{CH}_{3} \mathrm{SCH}_{3}$. The S-S linkage may thus be considered to slightly strengthen the proton-donating ability of a neighboring methyl group. But in no case is a $\mathrm{CH} \cdots \mathrm{O} \mathrm{H}$-bond strong enough to dominate the global minimum of any of these dimers.

\section{DISCUSSION}

The $\mathrm{CH}_{3} \mathrm{SH} / \mathrm{NMA}$ heterodimer has available to it a number of specific interactions in which it might engage. In terms of $\mathrm{H}$-bonds, the $\mathrm{SH}$ group can serve as a potent proton donor, and $\mathrm{S}$ can offer a protonaccepting site. The methyl hydrogens of $\mathrm{CH}_{3} \mathrm{SH}$ are activated to some extent by the neighboring electronegative $\mathrm{S}$ atom. The same can be said of the methyl groups of NMA which are both adjacent to the electron-withdrawing amide group. And of course the NH group of NMA represents a likely proton source. The carbonyl $\mathrm{O}$ is a prime proton acceptor, as is the $\mathrm{N}$. One usually thinks of the lone pairs of $\mathrm{O}$ as the source of charge transfer, but the $\mathrm{C}-\mathrm{O} \pi$ bond offers an alternative, given its concentration of density. The structures of the various minima, and their relative energies, allow a detailed comparison of the competitive strengths of each type of interaction, and an identification of any that might dominate.

The stability of the global minimum of the $\mathrm{CH}_{3} \mathrm{SH} / \mathrm{NMA}$ heterodimer rests not on one, but on several of these elements. The strongest component is a $\mathrm{H}$-bond involving a methyl $\mathrm{CH}$ of $\mathrm{CH}_{3} \mathrm{SH}$. The 
$\mathrm{O}$ lone pairs act as proton acceptor from the methyl group, as does the $\mathrm{CO} \pi$ bond. This $\mathrm{CH} \cdots \mathrm{O}$ interaction is supplemented by a $\mathrm{CH} \cdots \mathrm{S}$ H-bond, in this case involving a methyl group on the NMA. The fourth, and apparently weakest, interaction is not a H-bond at all. It involves a charge transfer from the $\mathrm{S}$ lone pairs, not to a $\mathrm{CH}$ group, but rather to the $\pi^{*}$ antibonding orbital of the $\mathrm{C}-\mathrm{O}$ bond. The next minimum also incorporates a $\mathrm{CH} \cdots \mathrm{S}$ H-bond, but substitutes the various other interactions of the global minimum for a SH$\cdots \mathrm{O} H$-bond, sacrificing $0.3 \mathrm{kcal} / \mathrm{mol}$ in the exchange. By losing the $\mathrm{CH} \cdots \mathrm{S}$ interaction, the third minimum is able to build a shorter and more linear $\mathrm{SH} \cdot . \mathrm{O} \mathrm{H}$-bond, forgoing any other noncovalent bonds, but in so doing rises in energy by $0.15 \mathrm{kcal} / \mathrm{mol}$. One may conclude therefore that a $\mathrm{SH} \cdots \mathrm{O} \mathrm{H}$-bond is not sufficiently strong, even if fully linear, that it can override those structures containing a number of different noncovalent bonds, even if each of the latter is individually weaker than a linear $\mathrm{SH}$... O bond.

The fourth minimum combines a large number of the various possible interactions. In addition to both $\mathrm{CH} \cdot \mathrm{O}$ and $\mathrm{CH} \cdot \mathrm{S} \mathrm{H}$-bonds, there are also $\mathrm{CH} \cdot \pi$ and $\mathrm{SH} \cdots \pi \mathrm{H}$-bonds wherein both protons extract density from the $\mathrm{CO} \pi$ bond, all combined with a $S_{\mathrm{lp}} \rightarrow \pi^{*}(\mathrm{CO})$ charge transfer. It is not until the fifth minimum, $0.6 \mathrm{kcal} / \mathrm{mol}$ less stable than the global structure, that one sees for the first time the charge transfer from a $\mathrm{N}$ lone pair to a $\sigma^{*}(\mathrm{SH})$ antibonding orbital. And even here in this case, the strength of this interaction is overshadowed by a $\mathrm{CH} \cdot \cdot \mathrm{O} / \mathrm{CH} \cdot \pi \mathrm{H}$-bond, so cannot be considered the primary stabilizing force.

It is only for the higher-energy minima that complexes characterized by a single stabilizing noncovalent bond become more prevalent. These isolated elements include a $\mathrm{SH} \cdot \cdot \mathrm{O}, \mathrm{NH} \cdot \cdot \mathrm{S}$. and $\mathrm{CH} \cdot \cdot \mathrm{O}$ H-bond. In summary, structures characterized by a combination of stabilizing forces are generally more stable than those containing a single element, even when the latter is able to attain its most stable geometry. If one were to consider only those structures with a single stabilizing force, then an order of diminishing strength can be obtained.

$$
\mathrm{SH} \cdots \mathrm{O}>\mathrm{NH} \cdots \mathrm{S}>\mathrm{CH} \cdots \mathrm{O}
$$

The pattern changes when the $\mathrm{SH}$ group is replaced by a second methyl in $\mathrm{CH}_{3} \mathrm{SCH}_{3}$. The

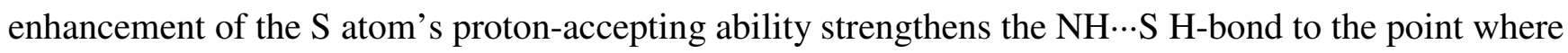
it is the sole contributor to the global minimum in the $\mathrm{CH}_{3} \mathrm{SCH}_{3} / \mathrm{NMA}$ heterodimer, with a binding energy of nearly $5 \mathrm{kcal} / \mathrm{mol}$. The structures of higher energy rely on multiple noncovalent bonds which again include combinations of $\mathrm{CH} \cdots \mathrm{O}, \mathrm{CH} \cdots \pi, \mathrm{CH} \cdots \mathrm{S}$, and $\mathrm{S}_{\mathrm{lp}} \rightarrow \pi^{*}(\mathrm{CO})$. A charge transfer from the $\mathrm{N}$ lone pair to a $\mathrm{CS} \sigma^{*}$ antibonding orbital contributes to several of these lower-lying minima, albeit not as much as do the forgoing $\mathrm{H}$-bonds which occur in combination with it. Other than the $\mathrm{NH} \cdots \mathrm{S} \mathrm{H}-$ bond 
occurring in the global minimum, the $\mathrm{CH} \cdots \mathrm{O} \mathrm{H}$-bond is the only other that occurs on its own in any of the structures, allowing an assessment of this H-bond energy of some 3.3-3.5 kcal/mol in this system.

When a second $\mathrm{S}$ atom is added to the monomer, as in $\mathrm{CH}_{3} \mathrm{SSCH}_{3}$, most of the minima, and certainly those of lowest energy, rely on multiple stabilizing interactions. The global minimum contains $\mathrm{CH} \cdot \pi$, $\mathrm{CH} \cdot \mathrm{O}, \mathrm{CH} \cdot \mathrm{S}$, as well as a $\mathrm{S}_{\mathrm{lp}} \rightarrow \pi^{*}(\mathrm{CO})$ interaction, as do many of the other structures. Another minimum, $0.2 \mathrm{kcal} / \mathrm{mol}$ higher than the first, adds another pair of charge transfers, both into the SS $\sigma^{*}$ antibonding orbital. Some of the charge is extracted from the $\mathrm{CO} \pi$ bond, but a roughly equal amount comes from the $\mathrm{CO} \pi^{*}$ orbital which is not completely vacant in the NMA monomer.

It is only for higher-energy structures that single interactions arise. The $\mathrm{NH} \cdots \mathrm{S}$ H-bond in structure $3 \mathbf{i}$ amounts to $4.40 \mathrm{kcal} / \mathrm{mol}$, just slightly less than the same interaction where $\mathrm{CH}_{3} \mathrm{SCH}_{3}$ acts as proton acceptor. Minima containing only a $\mathrm{CH} \cdots \mathrm{O}$ H-bond lead to an estimate of its binding energy of 3.6-3.7 $\mathrm{kcal} / \mathrm{mol}$, slightly higher than in the $\mathrm{CH}_{3} \mathrm{SCH}_{3} / \mathrm{NMA}$ heterodimer. Transfer into the $\mathrm{CS} \sigma^{*}$ antibond from the $\mathrm{N}$ lone pair does not occur until structure 31, and is overshadowed by the much stronger $\mathrm{NH} \cdots \mathrm{S}$ H-bond.

Numerical values of the H-bond energies are displayed in Table 4 for each of the S-containing molecules, derived from those structures in which that H-bond is the only stabilizing force. While $\mathrm{SH} \cdots \mathrm{O}$ is the strongest $\mathrm{H}$-bond in which $\mathrm{CH}_{3} \mathrm{SH}$ engages with NMA, it is only slightly stronger than $\mathrm{NH} \cdots \mathrm{S}$. Indeed, the latter H-bond is strengthened in $\mathrm{CH}_{3} \mathrm{SCH}_{3}$ and $\mathrm{CH}_{3} \mathrm{SSCH}_{3}$, invalidating any general statement about the relative strengths of $\mathrm{SH} \cdots \mathrm{O}$ and $\mathrm{NH} \cdots \mathrm{S}$. On the other hand, it would be fair to claim that the $\mathrm{CH} \cdots \mathrm{O} \mathrm{H}$-bond is weaker than either of the other two. Note however, that even here, one cannot ignore a H-bond energy of nearly $4 \mathrm{kcal} / \mathrm{mol}$, only slightly weaker than that in the water dimer. In contrast to $\mathrm{CH} \cdots \mathrm{O}$, there are no values reported in Table 4 for the energies of $\mathrm{CH} \cdots \mathrm{S} \mathrm{H}$-bonds. This absence is due to the fact that although the latter sort of interaction does occur in a number of minimum energy structures, it is not strong enough to represent the sole binding force in any. Likewise for the interactions involving charge transfers into the $\mathrm{S}-\mathrm{H}$ or $\mathrm{S}-\mathrm{C}$ antibonds.

With regard to some of the non-H-bonding sorts of noncovalent bonds, the binding energy for a $\mathrm{CS} \cdots \mathrm{N}$ bond was calculated earlier ${ }^{[44]}$ to be $0.7 \mathrm{kcal} / \mathrm{mol}$ when $\mathrm{CH}_{3} \mathrm{SH}$ was combined with $\mathrm{NH}_{3}$; the corresponding HS $\cdots \mathrm{N}$ bond is slightly weaker, $0.5 \mathrm{kcal} / \mathrm{mol}^{[42]}$. Given the lesser ability of the amide $\mathrm{N}$ lone pair to donate electrons, one would expect the noncovalent CS $\cdots \mathrm{N}$ and HS $\cdots \mathrm{N}$ bonds in the complexes pairing NMA with $\mathrm{CH}_{3} \mathrm{SH}$ and $\mathrm{CH}_{3} \mathrm{SCH}_{3}$ to be even weaker. It is for this reason that these noncovalent interactions are not primary factors in any of the complexes in which they occur. The insertion of a second $\mathrm{S}$ atom into $\mathrm{CH}_{3} \mathrm{SCH}_{3}$ might be expected to strengthen the potential SS $\cdots \mathrm{N}$ 
interaction by a small amount. But nonetheless, this bond remains weaker than other possible interactions, not making an appearance until structure $\mathbf{3 m}$, and even then it is eclipsed by a stronger $\mathrm{CH} \cdot \pi \mathrm{CO} \mathrm{H}$-bond. In fact, it would appear that the $\mathrm{CO} \pi$ bond serves as a superior source of electrons to the amide $\mathrm{N}$ lone pair, as the former yields higher values of $\mathrm{E}(2)$ and $\mathrm{SS} \cdot \pi(\mathrm{CO})$ bonds occur in more stable minima than does SS.*N.

There has been one previous computational study of complexes of NMA with S-containing systems of these sorts. Iwaoka et al ${ }^{[30,31]}$ first paired NMA with $\mathrm{CH}_{3} \mathrm{SCH}_{3}$, and identified only two minima, in contrast to our own finding of 10 distinct minima. Their global minimum $\mathrm{C}$ is stabilized by 2.9 $\mathrm{kcal} / \mathrm{mol}$, while our most stable minimum has a binding energy of nearly twice that value. Their structure $\mathrm{C}$ appeared to be similar to our dimer $2 \mathrm{c}$ in that it contained both a $\mathrm{CH} \cdots \mathrm{O}$ and $\mathrm{CS} \cdots \mathrm{N}$ pair of stabilizing interactions. Their secondary minimum D is similar to our own global minimum 2a, containing a $\mathrm{NH} \cdots \mathrm{S}$ H-bond.

The same research group also considered ${ }^{[30,31]}$ the $\mathrm{NMA} / \mathrm{CH}_{3} \mathrm{SSCH}_{3}$ heterodimer, again identifying only two minima on a surface that our calculations indicate contains 21 such minima. Their global minimum appears to correspond most closely to our own geometry $\mathbf{3 c}$, the third most stable structure. Our binding energy for $3 \mathrm{c}$ is $4.9 \mathrm{kcal} / \mathrm{mol}$, higher by $1.7 \mathrm{kcal} / \mathrm{mol}$ than their global minimum. The only other minimum identified by Iwaoka et al is rather similar to their global minimum, also seeming to contain a $\mathrm{CH} \cdots \mathrm{O}$ and $\mathrm{SS} \cdots \mathrm{O}$ pair of interactions. It would appear then that their superficial examination of the surface led them to ignore structures that are considerably more stable, bound by other interactions including $\mathrm{CH} \cdots \pi, \mathrm{CH} \cdots \mathrm{S}, \pi^{*}(\mathrm{CO}) \cdot \mathrm{S}, \mathrm{SS} \cdot \pi \pi$, and $\mathrm{NH} \cdots \mathrm{S}$ noncovalent bonds.

Some of the discrepancies may be due to their use ${ }^{[30,31]}$ of a $6-31 G^{*}$ basis set, much smaller and less flexible than the aug-cc-pVDZ set used here. There was apparently no attempt made to thoroughly search the potential energy surface for all minima, leaving the researchers with a suboptimal set. Also of note, their determination of the contributing factors in the stability of each structure was based primarily on geometric criteria, without a systematic evaluation of charge transfer energies.

A statistical analysis of protein crystal structures ${ }^{[30,31]}$ had suggested a propensity of the $S$ atom to lie above the amide plane when interacting with the amide $\mathrm{O}$ atom. This trend is confirmed by our calculations. For example in the complexes with $\mathrm{CH}_{3} \mathrm{SCH}_{3}$, the $\phi(\mathrm{NCO} \cdot \mathrm{S})$ dihedral angle in $\mathbf{2 b}$ is $91^{\circ}$, and $76^{\circ}$ in $2 \mathbf{i}$. Structures involving $\mathrm{CH}_{3} \mathrm{SSCH}_{3}$ had a similar tendency: the dihedral angle ranges from $68^{\circ}$ in $3 \mathbf{a}$ to $95^{\circ}$ in $\mathbf{3 b}$. This placement of the $S$ atom is consistent with the concept of transfer from the $\pi$ $\mathrm{CO}$ bond which is a common feature of these $\mathrm{O} \cdot \mathrm{S}$ interactions. 
It is worthwhile to consider how the results presented here might be altered if the model systems were enlarged to more accurately represent the actual protein segments. The $\mathrm{CH}_{3} \mathrm{SH}$ and $\mathrm{CH}_{3} \mathrm{SCH}_{3}$ models of Cys and Met, respectively, would probably not change much if their methyl groups were replaced by longer alkyl chains. Nor would one expect any changes in the $\mathrm{CH}_{3} \mathrm{SSCH}_{3}$ model of a disulfide linkage to affect the results by a significant amount. The replacement of NMA by a longer protein skeleton would probably have little influence upon the - $\mathrm{CO}-\mathrm{NH}$ - amide segment. On the other hand, the $\mathrm{CH}$ groups of the NMA would be surrounded on both sides by peptide groups, which would likely make them somewhat stronger proton donors. One might therefore anticipate some small strengthening of the $\mathrm{CH} \cdots \mathrm{S}$ H-bonds which occur in structures $\mathbf{1 b}, \mathbf{2} \mathbf{b}$, and $\mathbf{3 a}$, to name just a few. 


\section{References}

[1] G. A. Jeffrey, W. Saenger Hydrogen Bonding in Biological Structures; Springer-Verlag: Berlin, 1991.

[2] S. Scheiner Hydrogen Bonding. A Theoretical Perspective; Oxford University Press: New York, 1997.

[3] G. Gilli, P. Gilli The Nature of the Hydrogen Bond; Oxford University Press: Oxford, UK, 2009.

[4] Y. Gu, T. Kar, S. Scheiner. J. Mol. Struct. (Theochem) 2000, 500, 441-452.

[5] S. A. C. McDowell. Chem. Phys. Lett. 2006, 424, 239-242.

[6] Y. Gu, T. Kar, S. Scheiner. J. Mol. Struct. 2000, 552, 17-31.

[7] S. Scheiner, S. J. Grabowski, T. Kar. J. Phys. Chem. A 2001, 105, 10607-10612.

[8] E. S. Kryachko, S. Scheiner. J. Phys. Chem. A 2008, 112, 1940-1945.

[9] B. J. v. d. Veken, S. N. Delanoye, B. Michielsen, W. A. Herrebout. J. Mol. Struct. 2010, 976, $97-$ 104.

[10] T. S. Thakur, M. T. Kirchner, D. Bläser, R. Boese, G. R. Desiraju. Phys. Chem. Chem. Phys. 2011, 13, 14076-14091.

[11] S. J. Grabowski. J. Phys. Chem. A 2011, 115, 12789-12799.

[12] A. Karpfen, A. J. Thakkar. J. Chem. Phys. 2006, 124, 224313.

[13] N. G. Mirkin, S. Krimm. J. Phys. Chem. B 2008, 112, 15267-15268.

[14] S. M. LaPointe, S. Farrag, H. J. Bohórquez, R. J. Boyd. J. Phys. Chem. B 2009, 113, 10957-10964.

[15] S. Scheiner, T. Kar, J. Pattanayak. J. Am. Chem. Soc. 2002, 124, 13257-13264.

[16] S. Scheiner, T. Kar, Y. Gu. J. Biol. Chem. 2001, 276, 9832-9837.

[17] S. Scheiner. J. Phys. Chem. B 2005, 109, 16132-16141.

[18] S. Scheiner. J. Phys. Chem. B 2006, 110, 18670-18679.

[19] F. H. Allen, C. A. Baalham, J. P. M. Lommerse, P. R. Raithby. Acta Cryst. 1998, B54, 320-329.

[20] R. Paulini, K. Müller, F. Diederich. Angew. Chem., Int. Ed. Engl. 2005, 44, 1788-1805.

[21] F. R. Fischer, P. A. Wood, F. H. Allen, F. Diederich. Proc. Nat. Acad. Sci., USA 2008, 105, 1729017294.

[22] C. Fäh, L. A. Hardegger, M.-O. Ebert, W. B. Schweizer, F. Diederich. Chem. Commun. 2010, 46, 67-69.

[23] J. S. Murray, P. Lane, T. Clark, P. Politzer. J. Mol. Model. 2007, 13, 1033-1038.

[24] T. Clark, J. S. Murray, P. Lane, P. Politzer. J. Mol. Model. 2008, 14, 689-697.

[25] M. L. DeRider, S. J. Wilkens, M. J. Waddell, L. E. Bretscher, F. Weinhold, R. T. Raines, J. L. Markley. J. Am. Chem. Soc. 2002, 124, 2497-2505.

[26] T. K. Pal, R. Sankararamakrishnan. J. Phys. Chem. B 2010, 114, 1038-1049.

[27] C. E. Jakobsche, A. Choudhary, S. J. Miller, R. T. Raines. J. Am. Chem. Soc. 2010, 132, 66516653.

[28] R. E. Rosenfield, R. Parthasarathy, J. D. Dunitz. J. Am. Chem. Soc. 1977, 99, 4860-4862.

[29] F. T. Burling, B. M. Goldstein. J. Am. Chem. Soc. 1992, 114, 2313-2320.

[30] M. Iwaoka, S. Takemoto, S. Tomoda. J. Am. Chem. Soc. 2002, 124, 10613-10620.

[31] M. Iwaoka, S. Takemoto, M. Okada, S. Tomoda. Bull. Chem. Soc. Jpn. 2002, 75, 1611-1625.

[32] Y. Nagao, T. Hirata, S. Goto, S. Sano, A. Kakehi, K. Iizuka, M. Shiro. J. Am. Chem. Soc. 1998, 120, 3104-3110.

[33] C. Bleiholder, D. B. Werz, H. Koppel, R. Gleiter. J. Am. Chem. Soc. 2006, 128, 2666-2674.

[34] R. Gleiter, D. B. Werz, B. J. Rausch. Chem. Eur. J. 2006, 9, 2676-2683.

[35] L. Junming, L. Yunxiang, Y. Subin, Z. Weiliang. Struct. Chem. 2011, 22, 757-763.

[36] C. Bleiholder, R. Gleiter, D. B. Werz, H. Köppel. Inorg. Chem. 2007, 46, 2249-2260.

[37] S. Scheiner. J. Chem. Phys. 2011, 134, 094315. 
[38] S. Scheiner. J. Phys. Chem. A 2011, 115, 11202-11209.

[39] S. Scheiner. Chem. Phys. 2011, 387, 79-84.

[40] S. Scheiner, U. Adhikari. J. Phys. Chem. A 2011, 115, 11101-11110.

[41] U. Adhikari, S. Scheiner. J. Chem. Phys. 2011, 135, 184306.

[42] S. Scheiner. J. Chem. Phys. 2011, 134, 164313.

[43] U. Adhikari, S. Scheiner. Chem. Phys. Lett. 2011, 514, 36-39.

[44] U. Adhikari, S. Scheiner. J. Phys. Chem. A 2012, 116, 3487-3497.

[45] U. Adhikari, S. Scheiner. Chem. Phys. Lett. 2012, 532, 31-35.

[46] M. J. Frisch, G. W. Trucks, H. B. Schlegel, G. E. Scuseria, M. A. Robb, J. R. Cheeseman, G. Scalmani, V. Barone, B. Mennucci, G. A. Petersson, et al. Gaussian 09 Wallingford, CT, 2009.

[47] R. M. Osuna, V. Hernández, J. T. L. Navarrete, E. D’Oria, J. J. Novoa. Theor. Chem. Acc. 2011, $128,541-553$.

[48] M. G. Chudzinski, C. A. McClary, M. S. Taylor. J. Am. Chem. Soc. 2011, 133, 10559-10567.

[49] D. Hauchecorne, N. Nagels, B. J. v. d. Veken, W. A. Herrebout. Phys. Chem. Chem. Phys. 2012, 14, 681-690.

[50] Y. Zeng, X. Zhang, X. Li, L. Meng, S. Zheng. ChemPhysChem. 2011, 12, 1080-1087.

[51] J. Wu. Int. J. Quantum Chem. 2011, 111, 4247-4254.

[52] J. S. Murray, P. Lane, T. Clark, K. E. Riley, P. Politzer. J. Mol. Model. 2012, 18, 541-548.

[53] Q. Zhao, D. Feng, Y. Sun, J. Hao, Z. Cai. Int. J. Quantum Chem. 2011, 111, 3881-3887.

[54] E. Munusamy, R. Sedlak, P. Hobza. ChemPhysChem. 2011, 12, 3253-3261.

[55] D. Hauchecorne, A. Moiana, B. J. v. d. Veken, W. A. Herrebout. Phys. Chem. Chem. Phys. 2011, 13, 10204-10213.

[56] S. F. Boys, F. Bernardi. Mol. Phys. 1970, 19, 553-566.

[57] A. E. Reed, F. Weinhold, L. A. Curtiss, D. J. Pochatko. J. Chem. Phys. 1986, 84, 5687-5705.

[58] A. E. Reed, L. A. Curtiss, F. Weinhold. Chem. Rev. 1988, 88, 899-926. 
Table 1. Total interaction energy $\triangle \mathrm{E}$ and NBO second-order perturbation energy $\mathrm{E}(2)$ of its primary component interactions in complexes of NMA with $\mathrm{CH}_{3} \mathrm{SH}$. Energies in $\mathrm{kcal} / \mathrm{mol}$.

\begin{tabular}{|l|l|l|l|l|l|}
\hline & $-\Delta \mathrm{E}$ & interaction & $\mathrm{E}(2)$ & interaction & $\mathrm{E}(2)$ \\
\hline $\mathrm{a}$ & 4.60 & $\mathrm{CH} \cdot \cdot \mathrm{O}$ & 1.53 & $\mathrm{CH} \cdot \cdot \mathrm{S}$ & 1.06 \\
\hline & & $\mathrm{CH} \cdot \pi \mathrm{CO}$ & 1.11 & $\pi * \mathrm{CO} \cdot \cdot \mathrm{S}$ & 0.70 \\
\hline $\mathrm{b}$ & 4.27 & $\mathrm{SH} \cdot \cdot \mathrm{O}$ & 2.77 & $\mathrm{CH} \cdot \cdot \mathrm{S}$ & 1.42 \\
\hline & & $\mathrm{SH} \cdot \pi \mathrm{CO}$ & 1.84 & & \\
\hline c & 4.12 & $\mathrm{SH} \cdot \cdot \mathrm{O}$ & 10.19 & & \\
\hline $\mathrm{d}$ & 4.06 & $\mathrm{CH} \cdot \mathrm{O}$ & 1.04 & $\mathrm{CH} \cdot \cdot \pi \mathrm{CO}$ & 0.56 \\
\hline & & $\pi * \mathrm{CO} \cdot \mathrm{S}$ & 0.99 & $\mathrm{SH} \cdot \pi \mathrm{CO}$ & 0.50 \\
\hline & & $\mathrm{CH} \cdot \cdot \mathrm{S}$ & 0.76 & & \\
\hline $\mathrm{e}$ & 4.03 & $\mathrm{CH} \cdot \pi \mathrm{CO}$ & 2.11 & $\mathrm{HS} \cdot \cdot \mathrm{N}$ & 0.55 \\
\hline & & $\mathrm{CH} \cdot \cdot \mathrm{O}$ & 0.71 & & \\
\hline $\mathrm{h}$ & 3.95 & $\mathrm{NH} \cdot \cdot \mathrm{S}$ & 10.05 & & \\
\hline
\end{tabular}

Table 2. Total interaction energy $\triangle \mathrm{E}$ and NBO second-order perturbation energy $\mathrm{E}(2)$ of its primary component interactions in complexes of NMA with $\mathrm{CH}_{3} \mathrm{SCH}_{3}$. Energies in $\mathrm{kcal} / \mathrm{mol}$.

\begin{tabular}{|l|l|l|l|l|l|}
\hline & $-\Delta \mathrm{E}$ & interaction & $\mathrm{E}(2)$ & interaction & $\mathrm{E}(2)$ \\
\hline $\mathrm{a}$ & 4.93 & $\mathrm{NH} \cdot \cdot \mathrm{S}$ & 12.34 & & \\
\hline $\mathrm{b}$ & 4.88 & $\pi * \mathrm{CO} \cdot \mathrm{S}$ & 1.40 & $\mathrm{CH}^{\mathrm{a}} \cdot \cdot \pi \mathrm{CO}$ & 0.81 \\
\hline & & $\mathrm{CH}^{\mathrm{a}} \cdot \cdot \mathrm{O}$ & 1.24 & $\mathrm{CH}^{\mathrm{b}} \cdot \cdot \pi \mathrm{CO}$ & 0.61 \\
\hline & & $\mathrm{CH}^{\mathrm{b}} \cdot \cdot \mathrm{O}$ & 0.90 & & \\
\hline $\mathrm{c}$ & 4.22 & $\mathrm{CH} \cdot \cdot \pi \mathrm{CO}$ & 1.81 & $\mathrm{CS} \cdot \cdot \mathrm{N}$ & 0.75 \\
\hline $\mathrm{e}$ & 4.10 & $\mathrm{NH} \cdot \cdot \mathrm{S}$ & 2.53 & $\mathrm{CS} \cdot \cdot \mathrm{N}$ & 0.57 \\
\hline & & $\mathrm{CH} \cdot \cdot \mathrm{S}$ & 0.81 & & \\
\hline $\mathrm{f}$ & 3.46 & $\mathrm{CH} \cdot \cdot \mathrm{O}$ & 4.41 & & \\
\hline
\end{tabular}


Table 3. Total interaction energy $\triangle \mathrm{E}$ and $\mathrm{NBO}$ second-order perturbation energy $\mathrm{E}(2)$ of its primary component interactions in complexes of NMA with $\mathrm{CH}_{3} \mathrm{SSCH}_{3}$. Energies in $\mathrm{kcal} / \mathrm{mol}$.

\begin{tabular}{|l|l|l|l|l|l|}
\hline & $-\Delta \mathrm{E}$ & interaction & $\mathrm{E}(2)$ & interaction & $\mathrm{E}(2)$ \\
\hline $\mathrm{a}$ & 5.07 & $\mathrm{CH} \cdot \cdot \mathrm{CO}$ & 2.75 & $\mathrm{CH} \cdot \cdot \mathrm{O}$ & 1.22 \\
\hline & & $\mathrm{CH} \cdot \mathrm{S}$ & 2.35 & $\pi^{*} \mathrm{CO} \cdot \cdot \mathrm{S}$ & 0.76 \\
\hline $\mathrm{c}$ & 4.90 & $\mathrm{CH} \cdot \cdot \mathrm{O}$ & 1.49 & $\mathrm{SS} \cdot \cdot \pi \mathrm{CO}$ & 0.79 \\
\hline & & $\pi^{*} \mathrm{CO} \cdot \mathrm{S}$ & 1.00 & $\mathrm{SS} \cdot \cdot \pi^{*} \mathrm{CO}$ & 0.79 \\
\hline & & $\mathrm{CH} \cdot \cdot \mathrm{S}$ & 0.98 & $\mathrm{CH} \cdot \pi \mathrm{CO}$ & 0.67 \\
\hline $\mathrm{d}$ & 4.73 & $\mathrm{CH} \cdot \cdot \mathrm{S}$ & 2.82 & $\mathrm{CH}^{\mathrm{a}} \cdot \cdot \pi \mathrm{CO}$ & 0.86 \\
\hline & & $\mathrm{CH}{ }^{\mathrm{a}} \cdot \cdot \mathrm{O}$ & 2.19 & $\mathrm{CH}^{\mathrm{b}} \cdot \cdot \mathrm{O}$ & 0.62 \\
\hline & & $\mathrm{CH} \cdot \cdot \pi \mathrm{CO}$ & 1.67 & & \\
\hline $\mathrm{e}$ & 4.57 & $\mathrm{CH} \cdot \cdot \mathrm{S}$ & 1.86 & $\mathrm{CH} \cdot \cdot \mathrm{O}$ & 0.96 \\
\hline & & $\mathrm{CH} \cdot \cdot \pi \mathrm{CO}$ & 1.27 & $\mathrm{CH} \cdot \cdot \pi \mathrm{CO}$ & 0.80 \\
\hline & & $\mathrm{CH} \cdot \cdot \mathrm{O}$ & 1.87 & $\pi^{*} \mathrm{CO} \cdot \cdot \mathrm{S}$ & 0.55 \\
\hline $\mathrm{f}$ & 4.52 & $\mathrm{CH} \cdot \cdot \mathrm{S}$ & 3.59 & $\mathrm{CH} \cdot \pi \mathrm{CO}$ & 2.26 \\
\hline & & $\mathrm{CH} \cdot \cdot \mathrm{O}$ & 3.44 & & \\
\hline $\mathrm{g}$ & 4.50 & $\mathrm{CH} \cdot \cdot \mathrm{O}$ & 3.80 & $\mathrm{CH} \cdot \cdot \pi \mathrm{CO}$ & 2.56 \\
\hline & & $\mathrm{CH} \cdot \cdot \mathrm{S}$ & 3.59 & $\mathrm{CH} \cdot \cdot \mathrm{O}$ & 0.60 \\
\hline $\mathrm{h}$ & 4.48 & $\mathrm{NH} \cdot \mathrm{S}$ & 3.98 & $\mathrm{CH} \cdot \mathrm{S}$ & 0.73 \\
\hline $\mathrm{i}$ & 4.40 & $\mathrm{NH} \cdot \mathrm{S}$ & 8.73 & & \\
\hline $\mathrm{j}$ & 4.39 & $\pi * \mathrm{CO} \cdot \cdot \mathrm{S}$ & 1.05 & $\mathrm{SS} \cdot \cdot \pi * \mathrm{CO}$ & 0.77 \\
\hline & & $\mathrm{CH} \cdot \cdot \mathrm{O}$ & 1.05 & $\mathrm{SS} \cdot \cdot \pi \mathrm{CO}$ & 0.62 \\
\hline & & $\mathrm{CH} \cdot \cdot \mathrm{S}$ & 0.91 & $\mathrm{CH} \cdot \pi \mathrm{CO}$ & 0.61 \\
\hline $\mathrm{l}$ & 4.34 & $\mathrm{NH} \cdot \cdot \mathrm{S}$ & 7.37 & $\mathrm{CS} \cdot \cdot \mathrm{N}$ & 0.65 \\
\hline $\mathrm{m}$ & 4.21 & $\mathrm{CH} \cdot \pi \mathrm{CO}$ & 2.17 & $\mathrm{CH} \cdot \cdot \mathrm{O}$ & 0.70 \\
\hline & & $\mathrm{SS} \cdot \cdot \mathrm{N}$ & 1.08 & $\mathrm{SS} \cdot \cdot \pi * \mathrm{CO}$ & 0.61 \\
\hline $\mathrm{n}$ & 4.13 & $\mathrm{NH} \cdot \cdot \mathrm{S}$ & 6.49 & $\mathrm{CS} \cdot \cdot \mathrm{N}$ & 0.55 \\
\hline & & $\mathrm{CO} \pi * \cdot \cdot \mathrm{S}$ & 0.57 & & \\
\hline
\end{tabular}

Table 4. H-Bond energies ( $\mathrm{kcal} / \mathrm{mol})$ of S-containing molecules coupled with NMA

\begin{tabular}{|l|l|l|l|}
\hline & SH $\cdots \mathrm{O}$ & $\mathrm{NH} \cdots \mathrm{S}$ & $\mathrm{CH} \cdots \mathrm{O}$ \\
\hline $\mathrm{CH}_{3} \mathrm{SH}$ & 4.12 & 3.95 & 3.52 \\
\hline $\mathrm{CH}_{3} \mathrm{SCH}_{3}$ & - & 4.93 & 3.46 \\
\hline $\mathrm{CH}_{3} \mathrm{SSCH}_{3}$ & - & 4.40 & 3.74 \\
\hline
\end{tabular}




\section{FIGURE CAPTIONS}

Fig 1. Optimized geometries of various minima on the potential energy surface of the $\mathrm{CH}_{3} \mathrm{SH} / \mathrm{NMA}$ heterodimer. Large blue numbers represent binding energies, in kcal $/ \mathrm{mol}$. Distances in $\AA$ and angles in degrees.

Fig 2. Optimized geometries of various minima on the potential energy surface of the $\mathrm{CH}_{3} \mathrm{SCH}_{3} / \mathrm{NMA}$ heterodimer. Large blue numbers represent binding energies, in kcal/mol. Distances in $\AA$ and angles in degrees.

Fig 3. Optimized geometries of various minima on the potential energy surface of the $\mathrm{CH}_{3} \mathrm{SSCH}_{3} / \mathrm{NMA}$ heterodimer. Large blue numbers represent binding energies, in kcal/mol. Distances in $\AA$ and angles in degrees. 


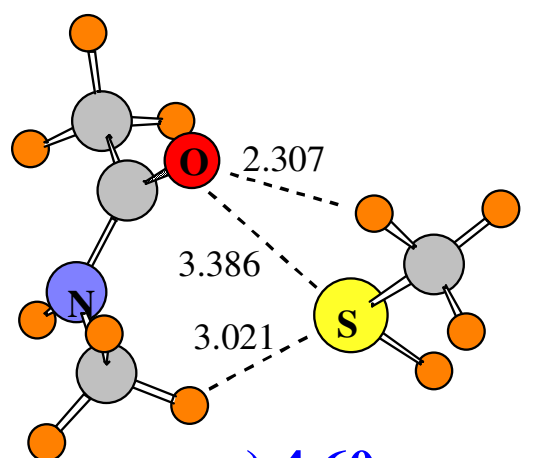

a) 4.60

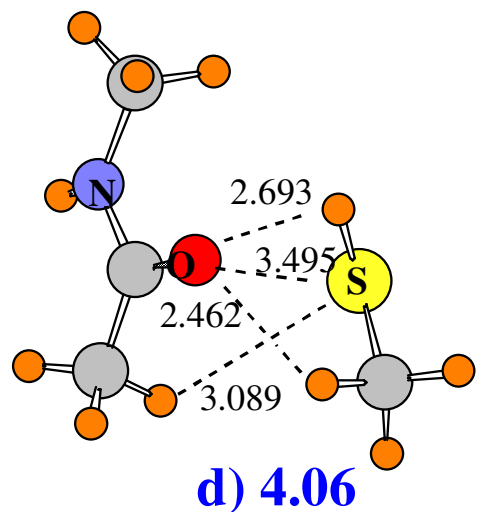

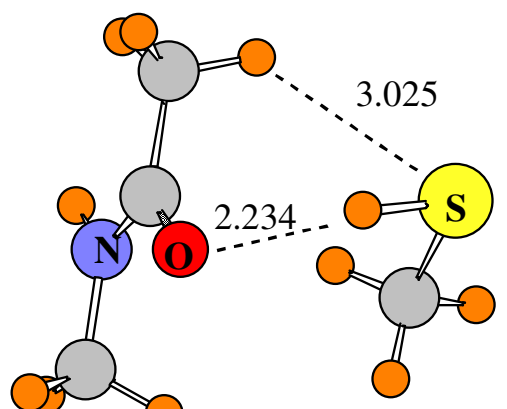

b) 4.27

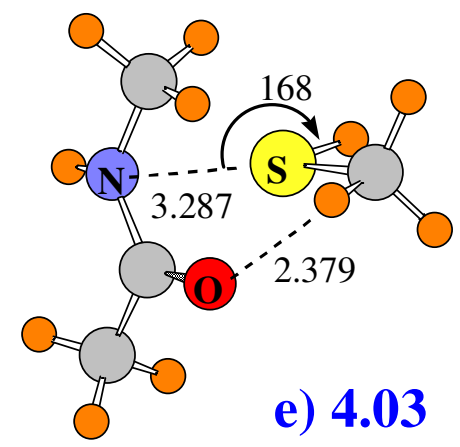

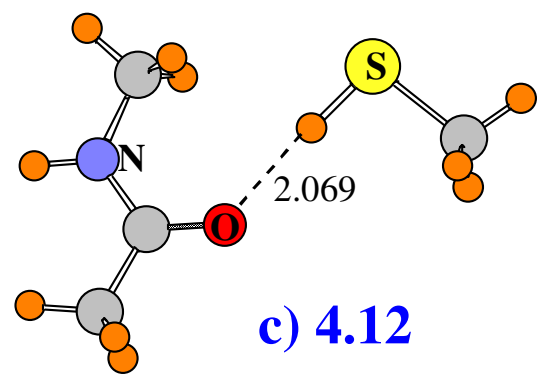

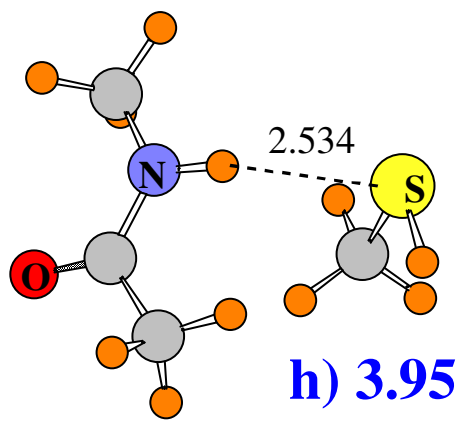

Fig 1. Optimized geometries of various minima on the potential energy surface of the $\mathrm{CH}_{3} \mathrm{SH} / \mathrm{NMA}$ heterodimer. Large blue numbers represent binding energies, in kcal/mol. Distances in $\AA$ and angles in degrees. 


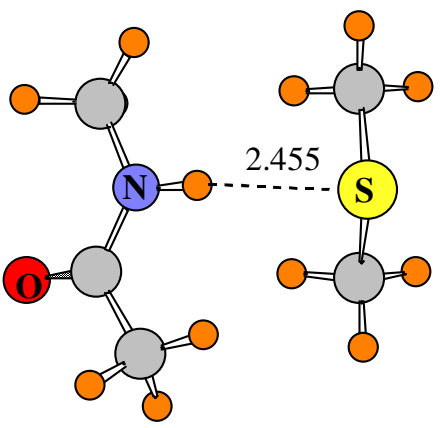

a) 4.93

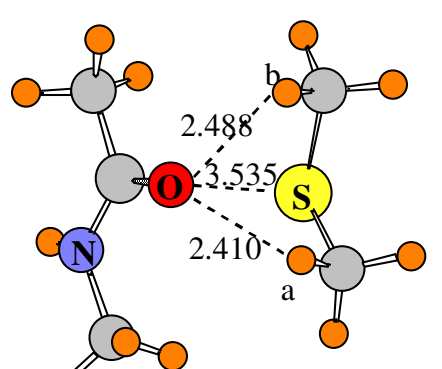

b) 4.88

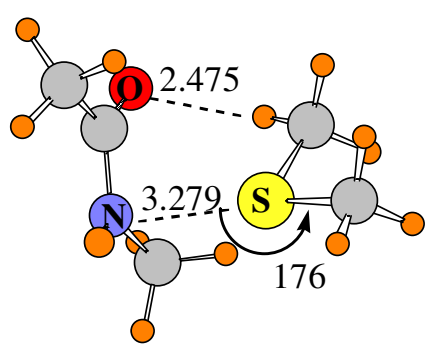

c) 4.22

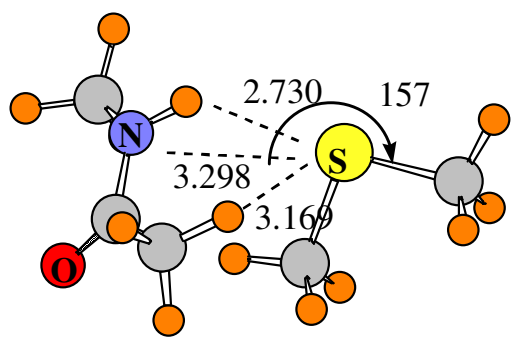

e) 4.10

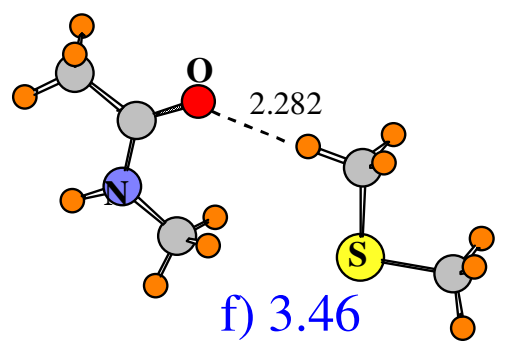

Fig 2. Optimized geometries of various minima on the potential energy surface of the $\mathrm{CH}_{3} \mathrm{SCH}_{3} / \mathrm{NMA}$ heterodimer. Large blue numbers represent binding energies, in kcal/mol. Distances in $\AA$ and angles in degrees. 

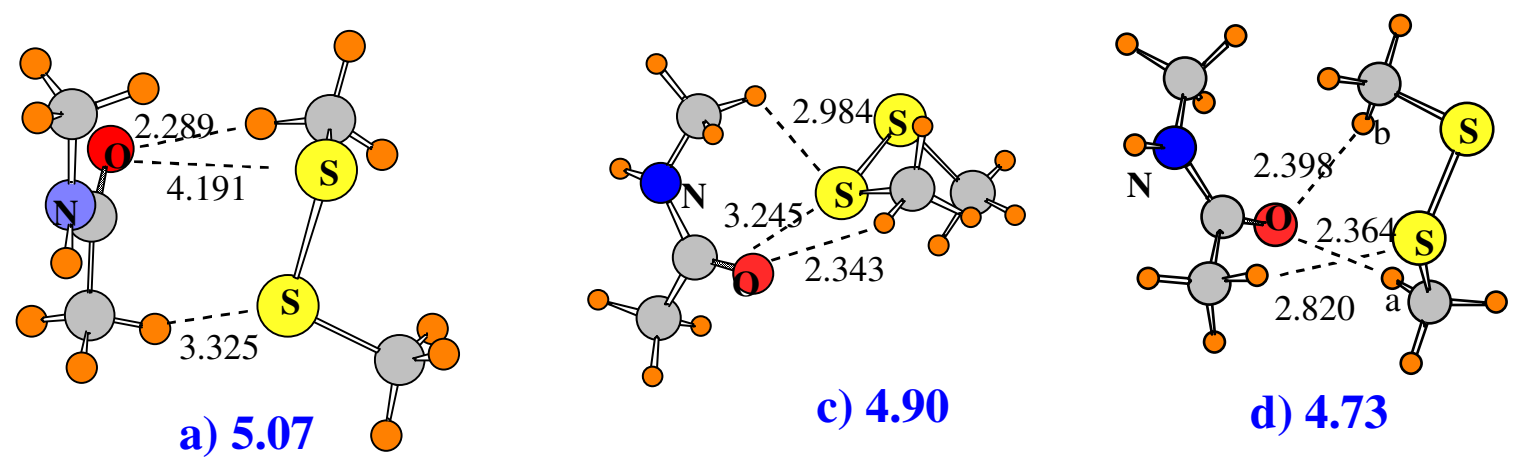

c) 4.90

d) 4.73
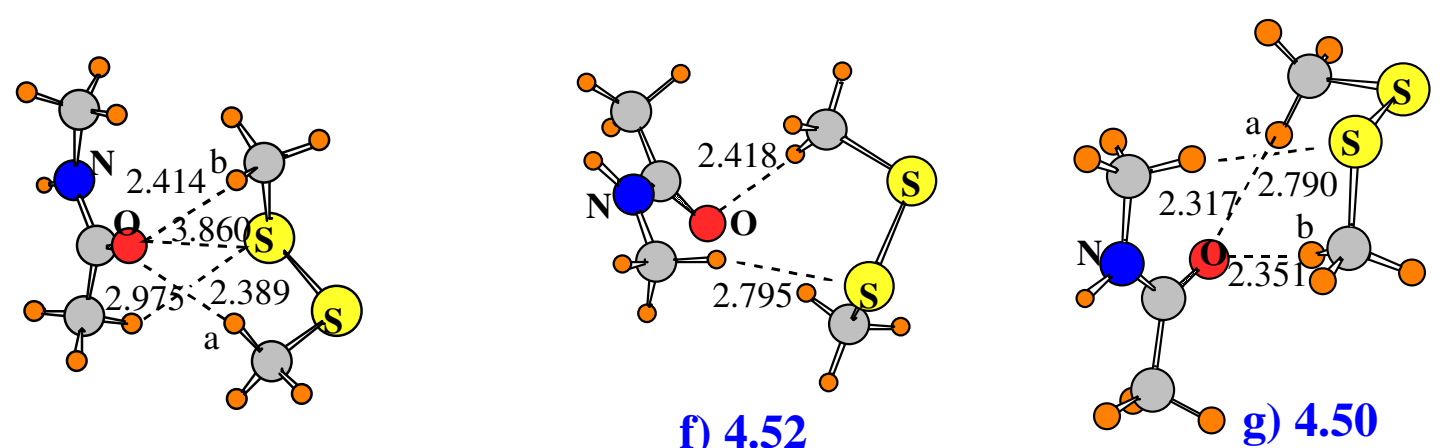

e) 4.57

f) 4.52

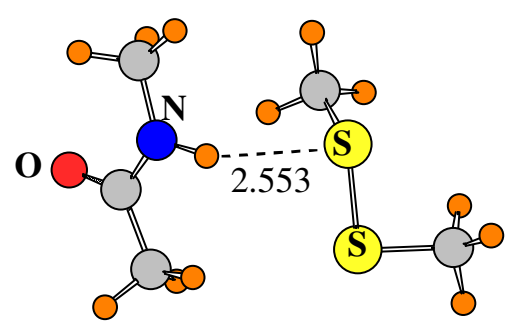

i) 4.40

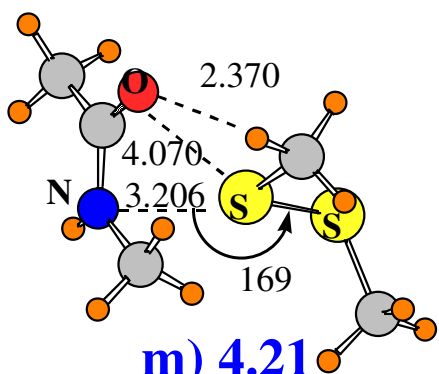

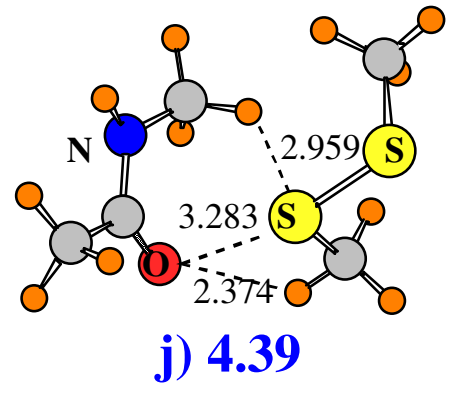

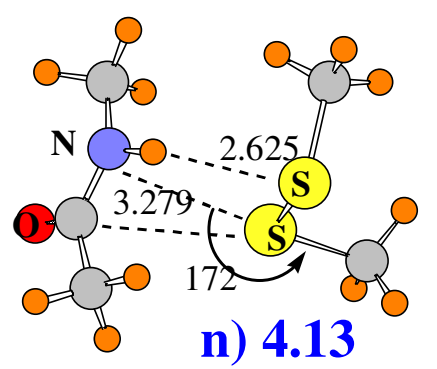

Fig 3. Optimized geometries of various minima on the potential energy surface of the $\mathrm{CH}_{3} \mathrm{SSCH}_{3} / \mathrm{NMA}$ heterodimer. Large blue numbers represent binding energies, in kcal/mol. Distances in $\AA$ and angles in degrees. 


\section{SUPPLEMENTARY INFORMATION}

Table S1. Total interaction energy $\triangle \mathrm{E}$ and NBO second-order perturbation energy $\mathrm{E}(2)$ of its primary component interactions in complexes of NMA with $\mathrm{CH}_{3} \mathrm{SH}$. Energies in $\mathrm{kcal} / \mathrm{mol}$.

\begin{tabular}{|l|l|l|l|l|l|}
\hline & $-\Delta \mathrm{E}$ & interaction & $\mathrm{E}(2)$ & interaction & $\mathrm{E}(2)$ \\
\hline $\mathrm{a}$ & 4.60 & $\mathrm{CH} \cdot \cdot \mathrm{O}$ & 1.53 & $\mathrm{CH} \cdot \mathrm{S}$ & 1.06 \\
\hline & & $\mathrm{CH} \cdot \cdot \pi \mathrm{CO}$ & 1.11 & $\pi * \mathrm{CO} \cdot \cdot \mathrm{S}$ & 0.70 \\
\hline $\mathrm{b}$ & 4.27 & $\mathrm{SH} \cdot \cdot \mathrm{O}$ & 2.77 & $\mathrm{CH} \cdot \cdot \mathrm{S}$ & 1.42 \\
\hline & & $\mathrm{SH} \cdot \pi \mathrm{CO}$ & 1.84 & & \\
\hline c & 4.12 & $\mathrm{SH} \cdot \cdot \mathrm{O}$ & 10.19 & & \\
\hline $\mathrm{d}$ & 4.06 & $\mathrm{CH} \cdot \cdot \mathrm{O}$ & 1.04 & $\mathrm{CH} \cdot \pi \mathrm{CO}$ & 0.56 \\
\hline & & $\pi * \mathrm{CO} \cdot \cdot \mathrm{S}$ & 0.99 & $\mathrm{SH} \cdot \pi \mathrm{CO}$ & 0.50 \\
\hline & & $\mathrm{CH} \cdot \cdot \mathrm{S}$ & 0.76 & & \\
\hline $\mathrm{e}$ & 4.03 & $\mathrm{CH} \cdot \cdot \mathrm{\pi CO}$ & 2.11 & $\mathrm{HS} \cdot \cdot \mathrm{N}$ & 0.55 \\
\hline & & $\mathrm{CH} \cdot \cdot \mathrm{O}$ & 0.71 & & \\
\hline $\mathrm{f}$ & 3.99 & $\mathrm{SH} \cdot \cdot \mathrm{O}$ & 10.47 & & \\
\hline $\mathrm{g}$ & 3.95 & $\mathrm{CH} \cdot \cdot \mathrm{O}$ & 1.91 & $\pi * \mathrm{CO} \cdot \cdot \mathrm{S}$ & 0.54 \\
\hline & & $\mathrm{CH} \cdot \cdot \mathrm{S}$ & 0.85 & $\mathrm{CH} \cdot \cdot \pi \mathrm{CO}$ & 0.50 \\
\hline $\mathrm{h}$ & 3.95 & $\mathrm{NH} \cdot \cdot \mathrm{S}$ & 10.05 & & \\
\hline $\mathrm{i}$ & 3.94 & $\mathrm{NH} \cdot \cdot \mathrm{S}$ & 9.32 & & \\
\hline $\mathrm{j}$ & 3.52 & $\mathrm{CH} \cdot \cdot \mathrm{O}$ & 4.65 & & \\
\hline $\mathrm{k}$ & 3.38 & $\mathrm{CH} \cdot \cdot \mathrm{O}$ & 4.81 & & \\
\hline
\end{tabular}

Table S2. Total interaction energy $\triangle \mathrm{E}$ and NBO second-order perturbation energy $\mathrm{E}(2)$ of its primary component interactions in complexes of NMA with $\mathrm{CH}_{3} \mathrm{SCH}_{3}$. Energies in $\mathrm{kcal} / \mathrm{mol}$.

\begin{tabular}{|l|l|l|l|l|l|}
\hline & $-\Delta \mathrm{E}$ & interaction & $\mathrm{E}(2)$ & interaction & $\mathrm{E}(2)$ \\
\hline $\mathrm{a}$ & 4.93 & $\mathrm{NH} \cdot \cdot \mathrm{S}$ & 12.34 & & \\
\hline $\mathrm{b}$ & 4.88 & $\pi^{*} \mathrm{CO} \cdot \cdot \mathrm{S}$ & 1.40 & $\mathrm{CH}^{\mathrm{a}} \cdot \cdot \pi \mathrm{CO}$ & 0.81 \\
\hline & & $\mathrm{CH}^{\mathrm{a}} \cdot \cdot \mathrm{O}$ & 1.24 & $\mathrm{CH}^{\mathrm{b}} \cdot \cdot \pi \mathrm{CO}$ & 0.61 \\
\hline & & $\mathrm{CH}^{\mathrm{b}} \cdot \cdot \mathrm{O}$ & 0.90 & & \\
\hline $\mathrm{c}$ & 4.22 & $\mathrm{CH} \cdot \cdot \mathrm{CO}$ & 1.81 & $\mathrm{CS} \cdot \cdot \mathrm{N}$ & 0.75 \\
\hline $\mathrm{d}$ & 4.21 & $\mathrm{CH} \cdot \cdot \pi \mathrm{CO}$ & 1.89 & $\mathrm{CS} \cdot \cdot \mathrm{N}$ & 0.70 \\
\hline $\mathrm{e}$ & 4.10 & $\mathrm{NH} \cdot \cdot \mathrm{S}$ & 2.53 & $\mathrm{CS} \cdot \cdot \mathrm{N}$ & 0.57 \\
\hline & & $\mathrm{CH} \cdot \cdot \mathrm{S}$ & 0.81 & & \\
\hline $\mathrm{f}$ & 3.46 & $\mathrm{CH} \cdot \cdot \mathrm{O}$ & 4.41 & & \\
\hline $\mathrm{g}$ & 3.27 & $\mathrm{CH} \cdot \cdot \mathrm{O}$ & 4.56 & & \\
\hline $\mathrm{h}$ & 2.47 & $\mathrm{CH} \cdot \cdot \cdot \pi \mathrm{CO}$ & 0.56 & $\mathrm{CH}$ & \\
\hline & & $\mathrm{CH} \cdot \cdot \mathrm{O}$ & 0.53 \\
\hline $\mathrm{i}$ & 1.91 & $\mathrm{CS} \cdot \cdot \pi \cdot \mathrm{CO}$ & 0.55 & & \\
\hline & & $\pi^{*} \mathrm{CO} \cdot \cdot \mathrm{S}$ & 0.53 & $\mathrm{CH} \cdot \cdot \mathrm{S}$ & 0.54 \\
\hline $\mathrm{j}$ & 0.93 & none & & & 0.45 \\
\hline
\end{tabular}


Table S3. Total interaction energy $\triangle \mathrm{E}$ and NBO second-order perturbation energy $\mathrm{E}(2)$ of its primary component interactions in complexes of NMA with $\mathrm{CH}_{3} \mathrm{SSCH}_{3}$. Energies in $\mathrm{kcal} / \mathrm{mol}$.

\begin{tabular}{|c|c|c|c|c|c|}
\hline & $-\Delta \mathrm{E}$ & interaction & $\mathrm{E}(2)$ & interaction & $\mathrm{E}(2)$ \\
\hline \multirow[t]{2}{*}{$\mathrm{a}$} & 5.07 & $\mathrm{CH} \cdot \pi \mathrm{CO}$ & 2.75 & $\mathrm{CH} \cdot \mathrm{O}$ & 1.22 \\
\hline & & $\mathrm{CH} \cdot \mathrm{S}$ & 2.35 & $\pi^{*} \mathrm{CO} \cdot \mathrm{S}$ & 0.76 \\
\hline \multirow[t]{2}{*}{$\mathrm{b}$} & 4.98 & $\mathrm{CH} \cdot \pi \mathrm{CO}$ & 2.72 & $\mathrm{CH} \cdot \mathrm{O}$ & 1.25 \\
\hline & & $\mathrm{CH} \cdot \mathrm{S}$ & 2.15 & $\pi^{*} \mathrm{CO} \cdot \mathrm{S}$ & 0.77 \\
\hline \multirow[t]{3}{*}{$\mathrm{c}$} & 4.90 & $\mathrm{CH} \cdot \mathrm{O}$ & 1.49 & $\mathrm{SS} \cdot \pi \mathrm{CO}$ & 0.79 \\
\hline & & $\pi * \mathrm{CO} \cdot \mathrm{S}$ & 1.00 & $\mathrm{SS} \cdot \pi * \mathrm{CO}$ & 0.79 \\
\hline & & $\mathrm{CH} \cdot \mathrm{S}$ & 0.98 & $\mathrm{CH} \cdot \pi \mathrm{CO}$ & 0.67 \\
\hline \multirow[t]{3}{*}{$\mathrm{d}$} & 4.73 & $\mathrm{CH} \cdot \mathrm{S}$ & 2.82 & $\mathrm{CH}^{\mathrm{a}} \cdot \cdot \pi \mathrm{CO}$ & 0.86 \\
\hline & & $\mathrm{CH}^{\mathrm{a}} \cdot \cdot \mathrm{O}$ & 2.19 & $\mathrm{CH}^{\mathrm{b}} \cdot . \mathrm{O}$ & 0.62 \\
\hline & & $\mathrm{CH}^{\mathrm{b}} \cdot \pi \mathrm{CO}$ & 1.67 & & \\
\hline \multirow[t]{3}{*}{$\mathrm{e}$} & 4.57 & $\mathrm{CH} \cdot \mathrm{S}$ & 1.86 & $\mathrm{CH}^{\mathrm{b}} \cdot . \mathrm{O}$ & 0.96 \\
\hline & & $\mathrm{CH}^{\mathrm{b}} \cdot \cdot \pi \mathrm{CO}$ & 1.27 & $\mathrm{CH}^{\mathrm{a}} \cdot \cdot \pi \mathrm{CO}$ & 0.80 \\
\hline & & $\mathrm{CH}^{\mathrm{a}} \cdot \cdot \mathrm{O}$ & 1.87 & $\pi^{*} \mathrm{CO} \cdot \mathrm{S}$ & 0.55 \\
\hline \multirow[t]{2}{*}{$\mathrm{f}$} & 4.52 & $\mathrm{CH} \cdot \mathrm{S}$ & 3.59 & $\mathrm{CH} \cdot \cdot \pi \mathrm{CO}$ & 2.26 \\
\hline & & $\mathrm{CH} \cdot \mathrm{O}$ & 3.44 & & \\
\hline \multirow[t]{2}{*}{$\mathrm{g}$} & 4.50 & $\mathrm{CH}^{\mathrm{a}} \cdot \mathrm{O}$ & 3.80 & $\mathrm{CH}^{\mathrm{b}} \cdot \cdot \pi \mathrm{CO}$ & 2.56 \\
\hline & & $\mathrm{CH} \cdot \mathrm{S}$ & 3.59 & $\mathrm{CH}^{\mathrm{b}} \cdot . \mathrm{O}$ & 0.60 \\
\hline $\mathrm{h}$ & 4.48 & $\mathrm{NH} \cdot \mathrm{S}$ & 3.98 & $\mathrm{CH} \cdot \mathrm{S}$ & 0.73 \\
\hline $\mathrm{i}$ & 4.40 & $\mathrm{NH} \cdot \mathrm{S}$ & 8.73 & & \\
\hline \multirow[t]{3}{*}{$\mathrm{j}$} & 4.39 & $\pi * \mathrm{CO} \cdot \mathrm{S}$ & 1.05 & $\mathrm{SS} \cdot \pi * \mathrm{CO}$ & 0.77 \\
\hline & & $\mathrm{CH} \cdot \mathrm{O}$ & 1.05 & $\mathrm{SS} \cdot \pi \mathrm{CO}$ & 0.62 \\
\hline & & $\mathrm{CH} \cdot \mathrm{S}$ & 0.91 & $\mathrm{CH} \cdot \cdot \pi \mathrm{CO}$ & 0.61 \\
\hline \multirow[t]{2}{*}{$\mathrm{k}$} & 4.36 & $\pi * \mathrm{CO} \cdot \mathrm{S}$ & 1.64 & $\mathrm{CH} \cdot \mathrm{S}$ & 0.69 \\
\hline & & $\mathrm{CH} \cdot . \mathrm{O}$ & 0.72 & $\mathrm{CH} \cdot \cdot \pi \mathrm{CO}$ & 0.55 \\
\hline 1 & 4.34 & $\mathrm{NH} \cdot \mathrm{S}$ & 7.37 & $\mathrm{CS} \cdot \cdot \mathrm{N}$ & 0.65 \\
\hline \multirow[t]{2}{*}{$\mathrm{m}$} & 4.21 & $\mathrm{CH} \cdot \pi \mathrm{CO}$ & 2.17 & $\mathrm{CH} \cdot \mathrm{O}$ & 0.70 \\
\hline & & $\mathrm{SS} \cdot \cdot \mathrm{N}$ & 1.08 & $\mathrm{SS} \cdot \pi * \mathrm{CO}$ & 0.61 \\
\hline \multirow[t]{2}{*}{$\mathrm{n}$} & 4.13 & $\mathrm{NH} \cdot \mathrm{S}$ & 6.49 & $\mathrm{CS} \cdot \mathrm{N}$ & 0.55 \\
\hline & & $\mathrm{CO} \pi * . . \mathrm{S}$ & 0.57 & & \\
\hline $\mathrm{O}$ & 4.10 & $\mathrm{NH} \cdot \mathrm{S}$ & 11.34 & $\mathrm{CH} \cdot \cdot \mathrm{N}$ & 0.50 \\
\hline $\mathrm{p}$ & 3.94 & $\mathrm{NH} \cdot \mathrm{S}$ & 13.24 & & \\
\hline$q$ & 3.79 & $\mathrm{CH} \cdot \mathrm{O}$ & 3.99 & $\mathrm{CH} \cdot \mathrm{S}$ & 2.33 \\
\hline $\mathrm{r}$ & 3.74 & $\mathrm{CH} \cdot \mathrm{O}$ & 4.94 & & \\
\hline $\mathrm{S}$ & 3.65 & $\mathrm{CH} \cdot \mathrm{O}$ & 4.57 & $\mathrm{CH} \cdot \mathrm{S}$ & 2.03 \\
\hline $\mathrm{t}$ & 3.62 & $\mathrm{CH} \cdot \cdot \mathrm{O}$ & 4.87 & & \\
\hline \multirow[t]{2}{*}{$\mathrm{u}$} & 2.09 & $\mathrm{CH} \cdot \mathrm{S}$ & 1.10 & $\mathrm{CS} \cdot \pi \mathrm{CO}$ & 0.55 \\
\hline & & $\mathrm{CH}^{\prime} \cdot \mathrm{S}^{\prime}$ & 0.74 & & \\
\hline
\end{tabular}




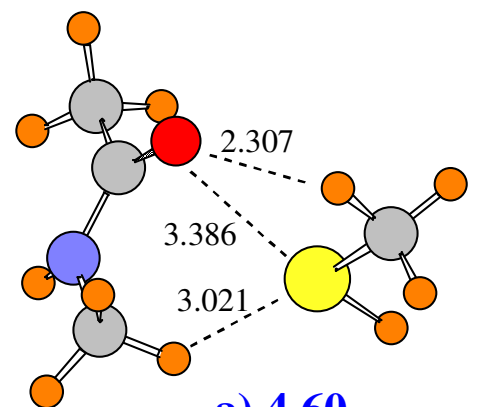

a) 4.60
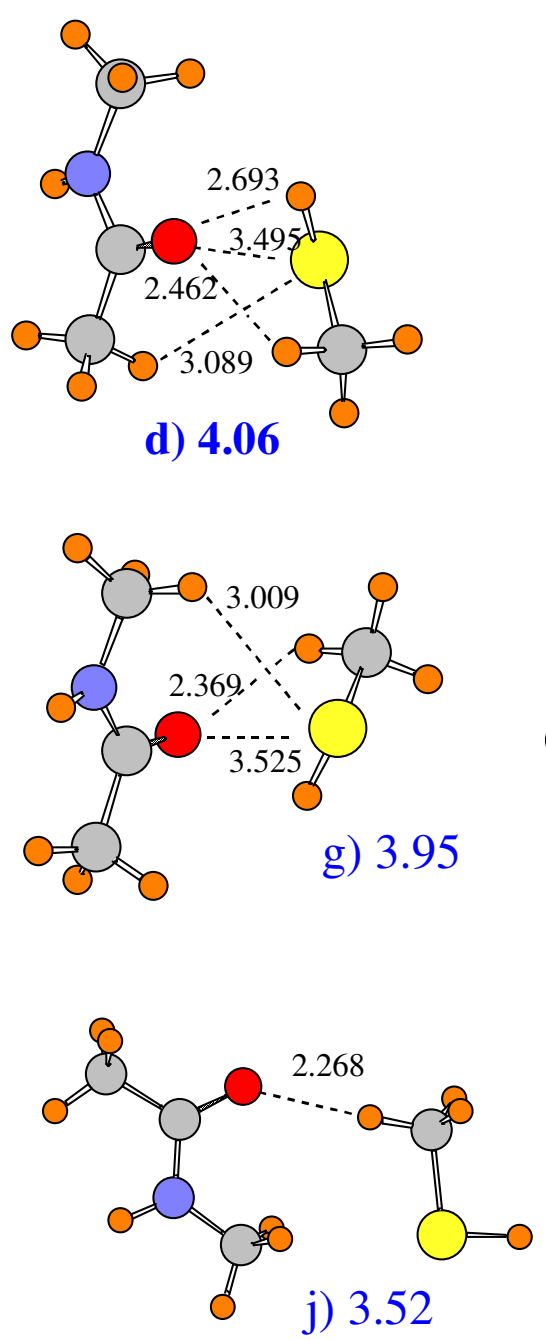

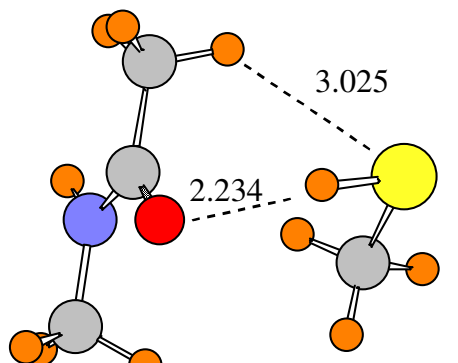

b) 4.27
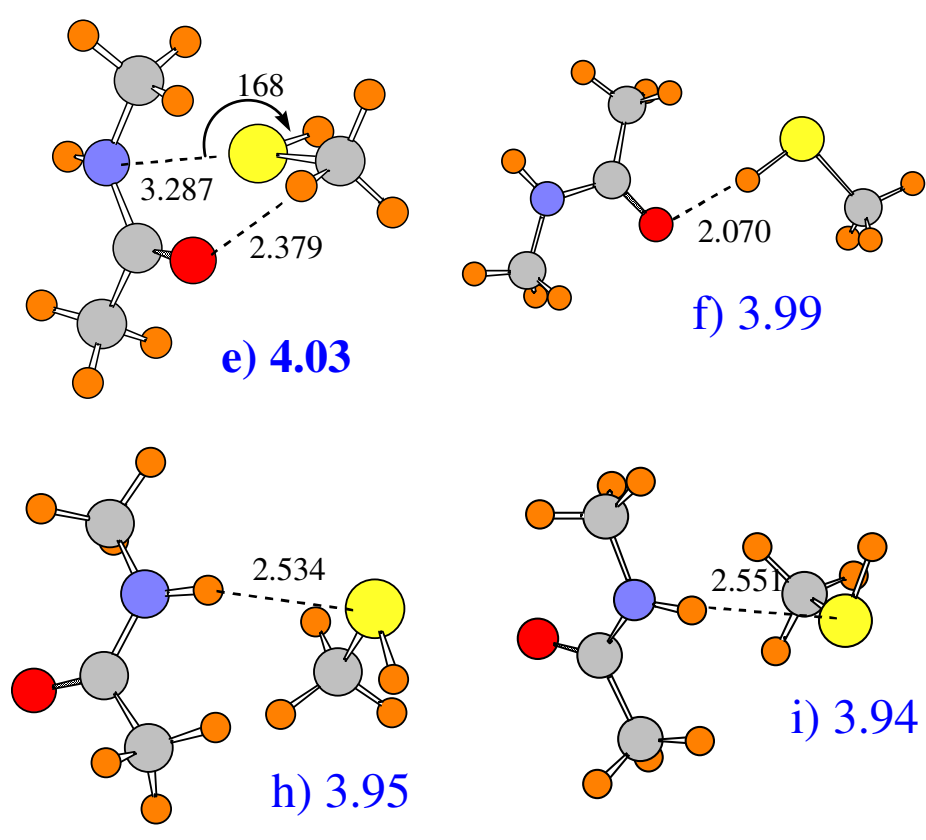

Fig S1. Optimized geometries of various minima on the potential energy surface of the $\mathrm{CH}_{3} \mathrm{SH} / \mathrm{NMA}$ heterodimer. Large blue numbers represent binding energies, in $\mathrm{kcal} / \mathrm{mol}$. Distances in $\AA$ and angles in degrees. 


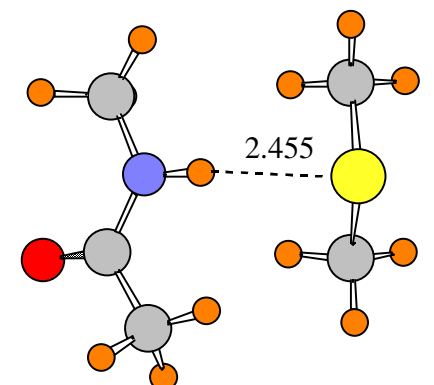

a) 4.93

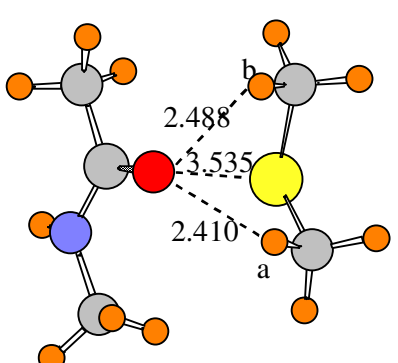

b) 4.88

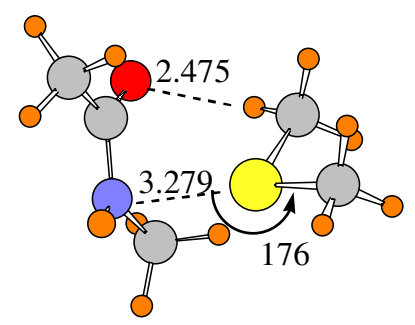

c) 4.22

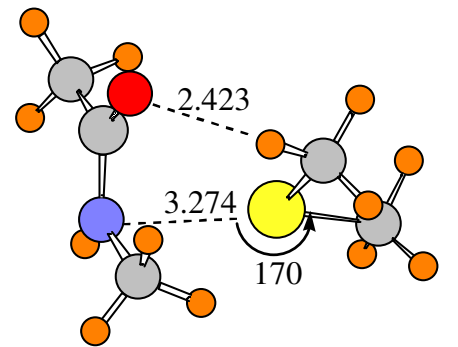

d) 4.21

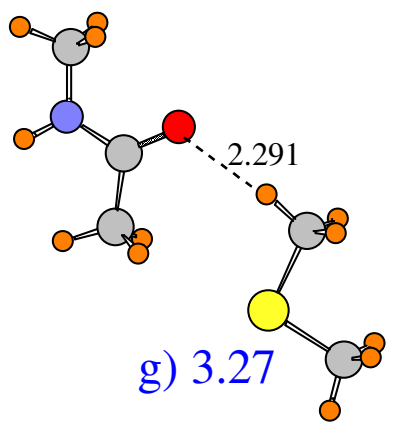

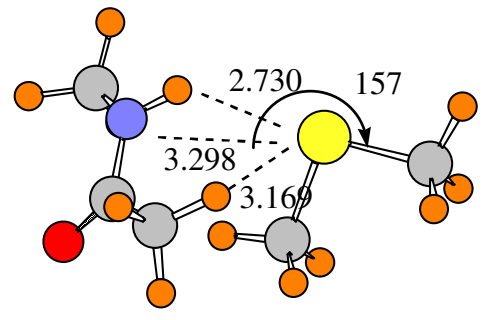

e) 4.10

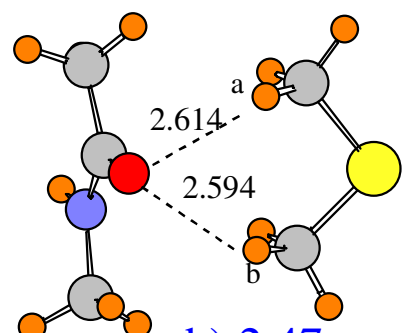

h) 2.47
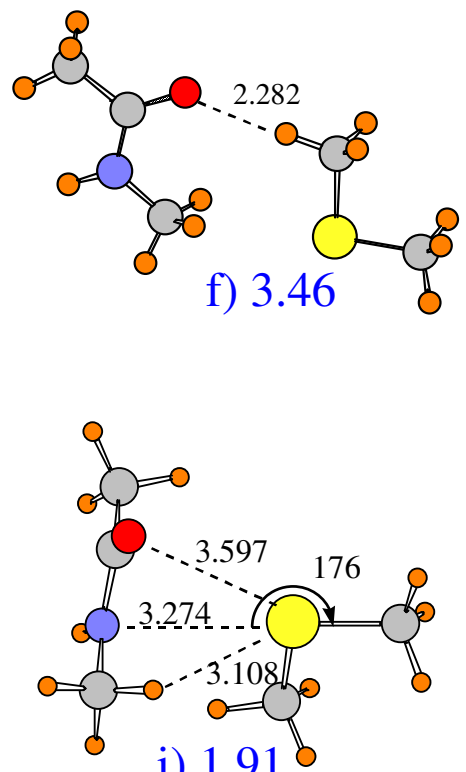

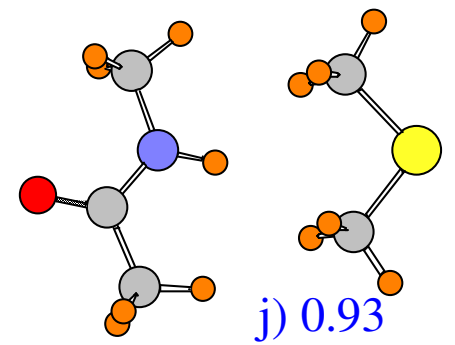

Fig S2. Optimized geometries of various minima on the potential energy surface of the $\mathrm{CH}_{3} \mathrm{SCH}_{3} / \mathrm{NMA}$ heterodimer. Large blue numbers represent binding energies, in kcal/mol. Distances in $\AA$ and angles in degrees. 

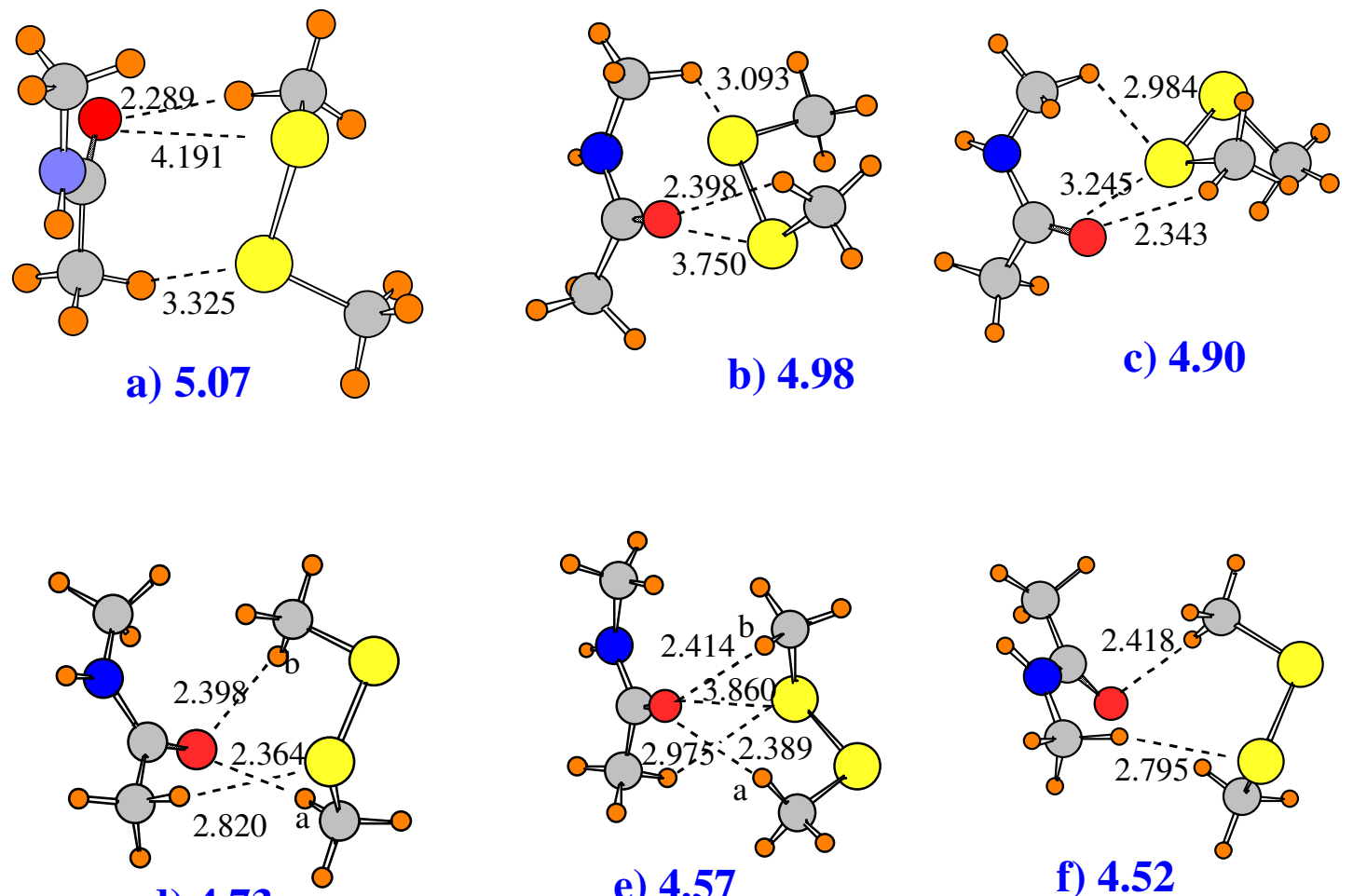

d) 4.73

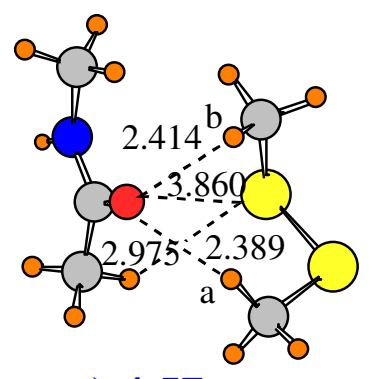

e) 4.57
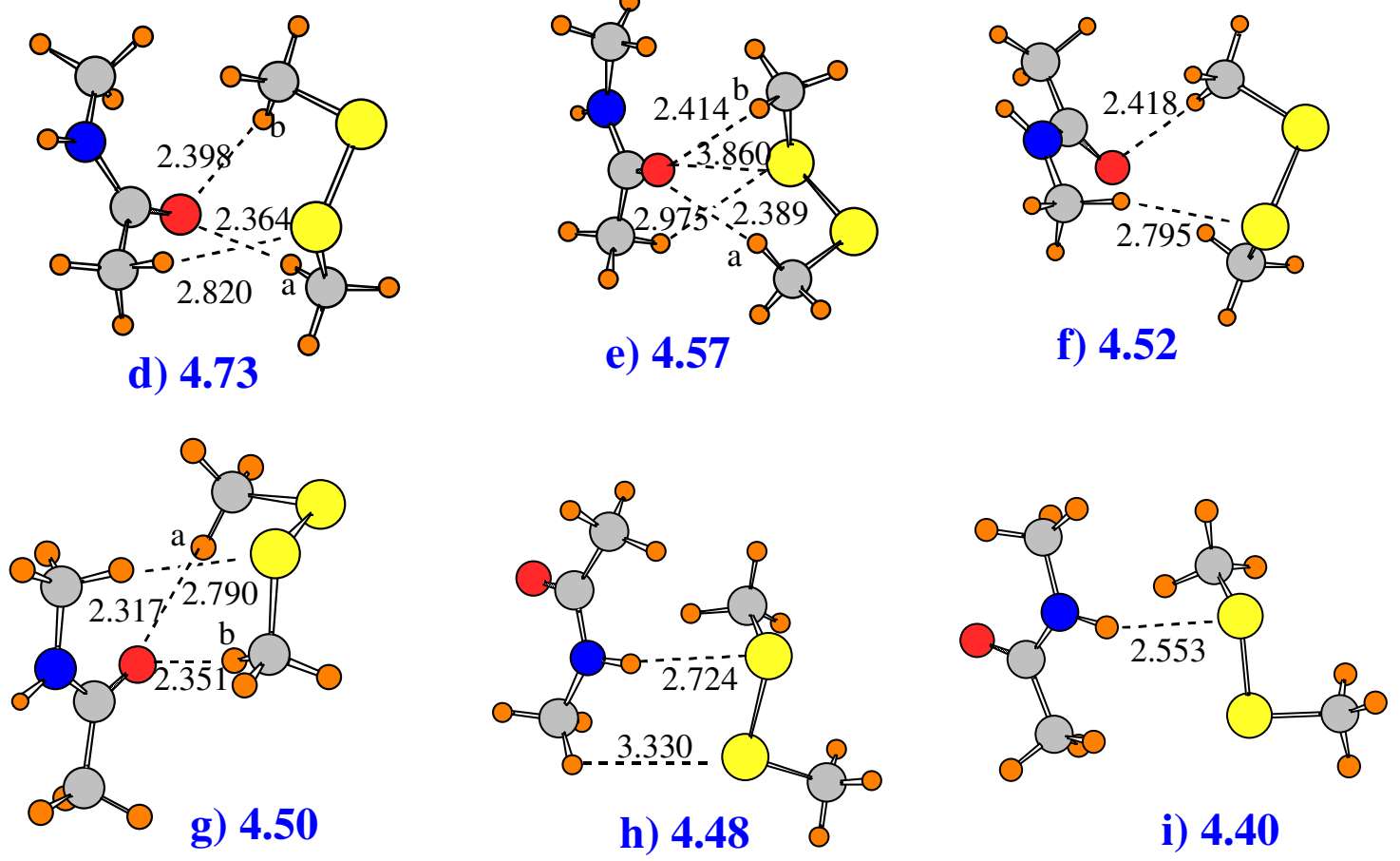

i) 4.40 

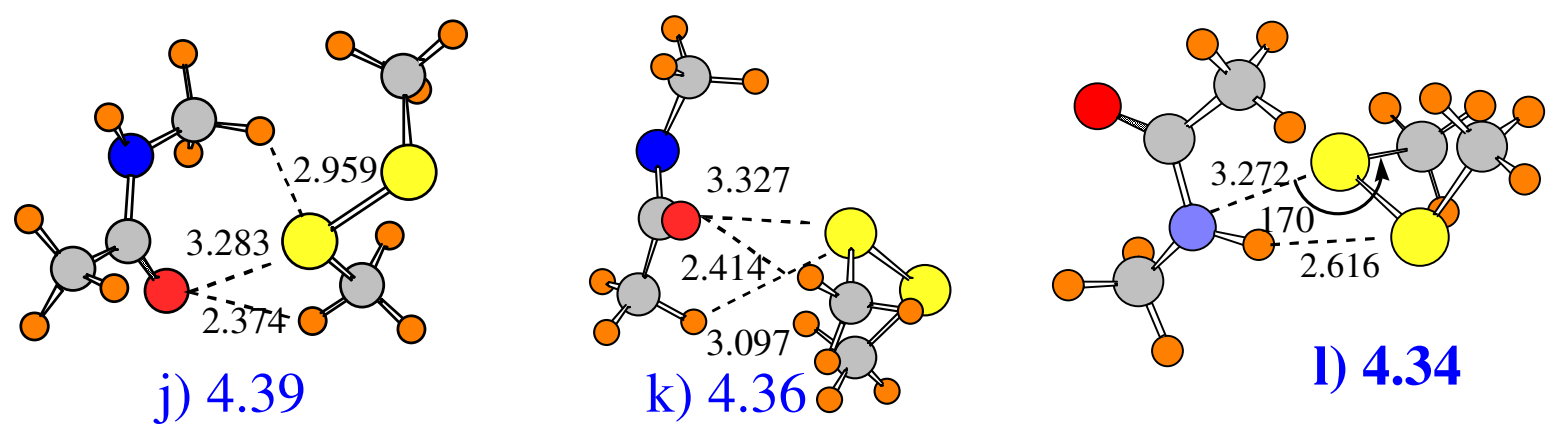

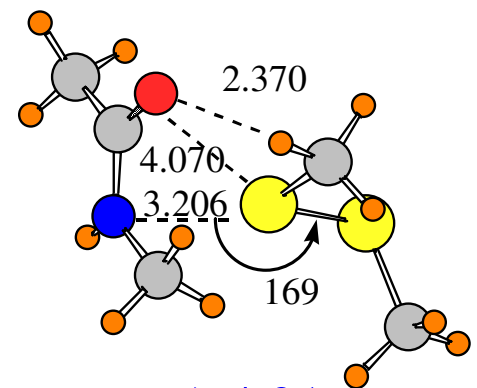

m) 4.21

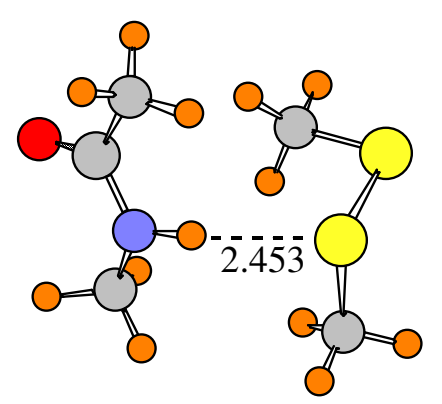

p) 3.94

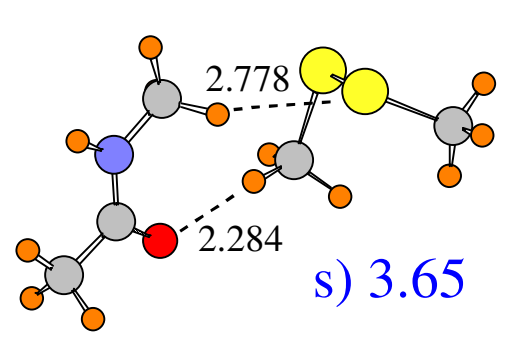

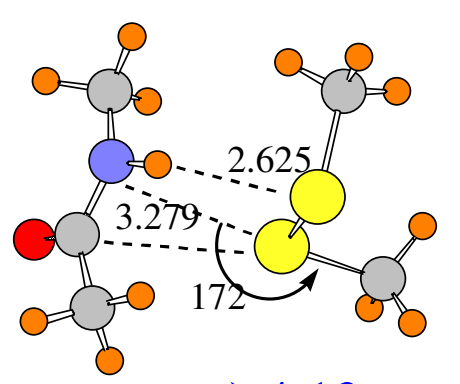

n) 4.13

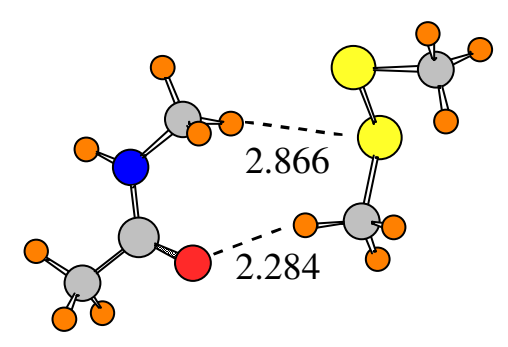

q) 3.79
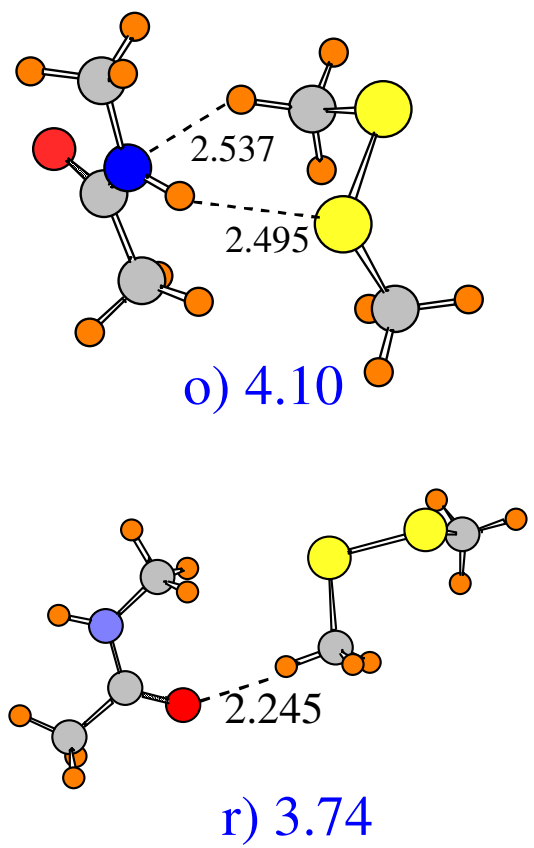

Fig S3. Optimized geometries of various minima on the potential energy surface of the $\mathrm{CH}_{3} \mathrm{SSCH}_{3} / \mathrm{NMA}$ heterodimer. Large blue numbers represent binding energies, in $\mathrm{kcal} / \mathrm{mol}$. Distances in $\AA$ and angles in degrees. 